\title{
Relational Contracting and the Myth of Trust: Control in a Co-opetitive Setting
}

\author{
Forthcoming in Management Accounting Research (available online from Aug 2016)
}

\author{
GRAFTON, Jennifer \\ Department of Accounting \\ The University of Melbourne \\ Victoria 3010 Australia \\ [T] +61383447662[F] +61393492397 \\ Email: j.grafton@unimelb.edu.au \\ MUNDY, Julia * \\ Centre for Governance, Risk and Accountability \\ Business School \\ The University of Greenwich \\ Old Royal Naval College \\ Greenwich London SE10 9LS UK \\ [T] +442083319695[F] +442083319007 \\ Email: j.mundy@greenwich.ac.uk
}

* Corresponding Author

Acknowledgements

We gratefully acknowledge the generous time contributions and co-operation of the firms whose data inform this study. Financial support for this study was provided by the Faculty of Business and Economics at the University of Melbourne, and the General Charitable Trust of the Chartered Institute of Management Accountants in the United Kingdom. We thank Anne Lillis, Shannon Anderson, and Henri Dekker for comments on earlier versions of this paper and acknowledge comments offered by seminar participants at the University of Melbourne, the University of New South Wales, the University of Technology, Sydney, La Trobe University and the mid-year management accounting section meeting of the AAA.

\begin{abstract}
In this paper, we investigate the role of formal and relational contracts in managing alliance risks that arise in co-opetitive collaborations. We undertake a case study of a co-opetitive sales alliance within the independent publishing sector, incorporating data from all firms to the alliance. We provide empirical evidence of the relational risks of misappropriation and opportunism as manifest in both vertical (buyer-supplier) and horizontal activities within the alliance and identify a further relational risk relating to concerns of introducing homogeneity into the product offerings of firms. We also examine the nature of compliance and regulatory risk, which is salient in this setting given the potential for anti-competitive behaviour towards customers and suppliers. We find that the firms mitigate alliance risks primarily through the use of relational contracts (informal self-enforcing agreements). Formal contracts are evident in the buyer-supplier relationship, but are used mainly for ex post co-ordination. We adopt an organisational economics perspective to explain the specific mechanisms that support
\end{abstract}


relational contracting between the firms. We find that shared values, implicit understandings, restricted membership, meetings, and collective sanctions encourage the firms to demonstrate commitment to the alliance, to diffuse information about partners' behaviours, and, crucially, to monitor partners. Informal agreements between partners are sustained by self-regulating behaviours, reinforced by the 'shadow of the future' in that firms have a great deal to gain from continued participation in the alliance and face losses if excluded. Notably, our findings support economic arguments that trust is a weak proxy for observable control mechanisms. Our study contributes to knowledge of the management of inter-firm risks in two significant ways. First, we draw on our empirical findings to develop an organising framework that presents a means of systematically investigating the mechanisms and factors that support the use of relational contracts. Second, by employing an economics approach to the management of alliance risks, we are able to present a richer and potentially more compelling view of inter-firm control than is traditionally presented in studies that rely on intra-firm notions of social controls, in particular trust.

Keywords: inter-organisational relationships, co-opetition, formal contracts, relational contracting, social controls, trust, enlightened self-interest.

Data Availability: We cannot make public the data used in this study due to confidentiality agreements with participating firms. 


\section{Relational Contracting and the Myth of Trust: Control in a Co-opetitive Setting}

\section{Introduction}

Collaborative relationships between competitors increasingly define the business landscape, spanning a range of industries (Bengtsson, Eriksson \& Wincent, 2010; Thomason, Simendinger \& Kiernan, 2013). In this study, we focus on the control of co-opetitive alliances, a specific, complex, form of collaboration between competitors. Engaging in co-opetitive activity entails "competing without having to kill the opposition and co-operation without having to ignore self-interest" (Brandenburger \& Nalebuff, 1996:4). Firms must protect and further their own competitive position, potentially at the expense of their partners, while concurrently combining resources in a joint effort to achieve a common goal and share in the resultant benefits (Czakon, Mucha-Kus \& Rogalski, 2014; Gnyawali \& Madhavan, 2001). Despite evidence that alliances between competitors are more likely to fail than those between non-competing partners (Park and Russo, 1996), and despite calls to extend management accounting and control studies of inter-firm relationships beyond buyer-supplier exchanges (Caglio \& Ditillo, 2008), co-opetitive alliances remain under-examined.

In this study we investigate the use of formal and relational contracting to manage alliance risks in coopetitive settings. Extant literature has focused extensively on formal contracts, despite evidence that these are often incomplete and that other mechanisms are employed to manage inter-firm relations (Anderson \& Dekker, 2014). Informal self-enforcing agreements between firms (relational contracts) rely on a range of social and other relationship-based control mechanisms and are sustained by the expected value of the future relationship (Baker, Gibbons \& Murphy, 2002; Williamson, 1979). The literature is equivocal as to whether relational contracts are substitutes or complements for formal contracts, although the relation between them appears to be context specific (Cao \& Lumineau, 2015).

While the notion of relational contracting has been considered extensively in the management and economics literatures there is little empirical evidence of its role in managing alliance risks (for recent exceptions, see Neumann, 2010; Windolph \& Moeller, 2012). Furthermore, it remains under- 
conceptualised (Cao \& Lumineau, 2015; Schepker, Oh, Martynov \& Poppo, 2014), and underresearched, with most studies focussing predominantly on the use of social controls for relational contracting (for example, Dekker, 2004; Neumann, 2010). Social controls, commonly captured in these studies through notions of shared values and trust, represent one aspect of relational contracting (Jones et al, 1997), and hence offer only a partial explanation of the governance arrangements between alliance partners. By extending the notion of relational contracting beyond the use of social controls, we thus address recent concerns in the management control literature about the use of intra-firm concepts in the study of inter-firm relationships (cf. Caglio \& Ditillo, 2008; Dekker, 2015).

Broadly similar conceptualisations of relational contracting are evident in both the management and economics-based literatures, but they differ significantly in one particular respect. While the management literature relies heavily on trust-based constructs to explain relational contracting, organisational economic theory contends that the concept of 'trust' offers a largely impoverished explanation of the nature of relationships between firms (cf. Chaserant, 2003; Williamson, 1993). Economic exchanges require safeguards to protect investments from opportunistic others; employing the concept of 'trust' obscures the nature, use, and rationale underpinning such protection (Williamson, 1993). In economic terms, mechanisms used to manage alliance risk lead to ex post labelling of trust (Barney et al, 1994); it is these mechanisms that must be carefully identified in order to understand better the nature of inter-firm control. Trust is thus regarded in the study of inter-firm relations as an inappropriate and weak proxy for observable mechanisms of control. First introduced into management control research by Tomkins in 2001, the concept of trust as an analytical device to explain inter-firm relations remains unchallenged in the management control literature. The current study, with its focus on a broad conceptualisation of relational contracting, therefore provides an opportunity to investigate inter-firm exchanges through an economics lens, rather than from the narrow management perspective traditionally adopted in the control literature.

We pay particular attention to specific alliance risks that formal and relational contracts are designed to mitigate in a co-opetitive setting (cf. Caglio \& Ditillo, 2008), moving beyond the traditional use of 
transaction characteristics (asset specificity, uncertainty, and frequency) as proxies for such risks. Anderson, Christ, Dekker, and Sedatole (2015) argue that the use of transaction characteristics as proxies for risk emphasises risk at the level of the transaction at the expense of broader risks within the totality of the alliance.

We undertake a case study of a co-opetitive alliance within the independent publishing sector in the United Kingdom, drawing on interview data collected from all partners to the alliance. We thus respond to calls for more field research in this area in order to provide contextual richness to our current understanding of relational contracts (Cao \& Lumineau, 2015). Our study investigates a complex setting involving the governance of both buyer-supplier (vertical) and horizontal activities between competing partners. This co-opetitive context is characterised by a non-equity based relationship and the absence of a super-ordinate governing authority. Our setting allows us to consider how alliance type, beyond the more frequently researched dyadic buyer-supplier context, influences the risks that arise and the subsequent control mechanisms employed to mitigate these risks (cf. Anderson, Christ, Dekker \& Sedatole, 2014; Cao \& Lumineau, 2015; Caglio \& Ditillo, 2008; Dekker, 2015). We also examine the interplay between relational and formal contracting in managing these risks (Cau \& Lumineau, 2015).

We focus primarily on the relational risks within the alliance given that joint activity between competitors is argued to offer greater incentives and potential for opportunism (Park \& Russo, 1996; Tidström, 2014). ${ }^{1}$ We find evidence of wide-ranging appropriation concerns within the alliance, consistent with this view. However, we also find that the value of the alliance to each firm reduces their motivation to engage in such behaviours. Each firm's motivation to act opportunistically is further tempered by the ability of their partners to better identify such opportunistic behaviours. We also identify a type of relational risk unique to co-opetitive alliances, not previously identified in the literature, that we refer to as the risk of homogeneity in firm identity and product offering. This risk

\footnotetext{
${ }^{1}$ Performance risk, the risk that collaborative efforts are unsuccessful despite full co-operation between parties, is another crucial matter for inter-firm relationships (Das \& Teng, 2001; Langfield-Smith, 2008; Schreiner et al., 2009). We do not focus on the performance risk, or the risk of 'co-ordination failures' in this study. We do however, highlight pertinent co-ordination concerns and responses in the presentation and discussion of our findings.
} 
arises from unwitting imitation between competitors as they share information and engage in other interfirm exchanges. Finally, we highlight the salience of regulatory risk, in the co-opetitive setting. Regulatory risk arises because competing partners must avoid both actual and perceived anticompetitive behaviour.

The firms in our study manage the alliance risks inherent in co-opetitive relationships through a combination of formal and relational contracting. We find that formal contracts manage the buyersupplier relationship between partners to the alliance. However, these are used mainly for ex post coordination of these vertical activities between firms (i.e. to manage the performance rather than the relational risks of the alliance). While the formal contracts do include measurable targets, we find that attainment of these targets is regarded by the purchasing partners as secondary to sustaining the alliance. This is consistent with the inclusion of formal contracts prepared for the management of buyer-supplier activities to indirectly mitigate alliance risks associated with the horizontal activities of the alliance we study. To this end, formal contracts address regulatory risk by addressing perceptions of anticompetitive practices and ensuring compliance with relevant legislation.

The governance of the alliance relies heavily on relational contracting. Specifically, the firms in our study make extensive use of shared values, group norms, meetings and informal gatherings, partner selection, restricted access (number of partners to the alliance), and the threat of collective sanctions to manage various relational risks associated with the co-opetitive alliance. Relational contracting establishes credible commitments between firms. Firms act according to principles of 'enlightened selfinterest', in that they have a great deal to gain from continued participation in a range of collaborations and face potentially significant losses if excluded. Furthermore, by co-operating with a select group of firms who share similar knowledge and expertise, firms are aware that their partners can readily identify behaviours that run counter to the norms of the alliance and adjust their behaviours accordingly. We therefore demonstrate the critical role of self-regulating behaviour by firms in governing and sustaining the alliance. Our findings also indicate that relational contracting can substitute for formal contracting in managing alliance risks in a co-opetitive setting. However, we find that the choice of relational 
contracting in this setting is influenced by the existence of social ties and shared values that pre-date formal contracts and the preferences of alliance partners for informal agreements. Finally, the use of relational contracting in the sales alliance is not unique to the collaborative activities we study; we find it extends to other alliances across the value chain in which the same partners are involved. This suggests that relational contracts need not be re-developed or re-negotiated when new alliances are forged between partners.

Our study contributes to the literature in a number of ways. First, we document specific alliance risks (control problems) evident in co-opetitive exchange. By moving beyond transaction characteristics as proxies for such risks we are able to demonstrate the range of control problems that manifest in a coopetitive context. Typically, it is claimed that control problems, in particular relational risks, are likely to be 'more acute' in co-opetitive alliances, given that firms are better positioned to identify and appropriate resources of value from their partners (Caglio \& Ditillo, 2008). However, our setting enables us to demonstrate how firms with an in-depth understanding of their partners' businesses are also better positioned to identify and monitor the opportunities and incentives available to their partners, which mitigates opportunistic behaviour in co-opetitive alliances. Thus, we demonstrate empirically the value of studying specific relational risks, beyond the level of the transaction, within an alliance (Anderson et al, 2014; Caglio \& Ditillo, 2008; Neumann, 2010). Furthermore, our identification of a new type of regulatory risk, not previously acknowledged in the literature, demonstrates the importance of seeking out novel contexts in which to investigate alliance risks. By moving beyond buyer-supplier relationships, we are able to demonstrate how alliance risks manifest in a complex setting involving both vertical and horizontal relationships. This provides us with a richer portrayal of the risks faced by firms and a more meaningful basis on which to explain the resulting governance mechanisms observed.

Second, we make several contributions to the empirical literature on relational contracting. We adopt an economic perspective in order to investigate a broad set of relational mechanisms beyond social controls. Our approach enables us to explain inter-firm governance in terms of calculative behaviours driven by self-interested notions of gains and losses. Such a perspective provides an alternative and 
potentially more compelling view of inter-firm governance from that traditionally presented in studies that rely on notions of social controls or simply 'trust'. Our approach enables us to present a richer and more comprehensive understanding of relational contracting than is currently evident from empirical research.

We draw on our data to develop a comprehensive organising framework that captures notions of relational contracting most frequently included in the literature and structures them into the mechanisms of relational contracting that mitigate risks between firms, the factors that sustain the use of these mechanisms, and the outcomes of relational contracting. This framework can provide a basis for systematic future research into the role of relational contracting in the management of inter-firm relations. We also contribute to the relational contracting literature by demonstrating the use of relational contracting across multiple alliances. We thus demonstrate the value of extending research in management control beyond the scope of inter-firm buyer-supplier exchanges to understand the salience and potential efficiencies of relational contracting in managing a broader nexus of exchange between partners at a network level (Caglio \& Ditillo, 2008).

Third, we address ongoing debates relating to the interplay of formal and relational contracting in interfirm relationships. Recent contributions to these debates acknowledge the importance of context when examining the relationship between formal and relational contracting (see Cao \& Lumineau, 2015 for an overview of this literature). We demonstrate that relational contracting can substitute for formal contracting in a co-opetitive setting. While this finding contradicts previous findings in complex interfirm settings, we explain how this can be understood in the context of how other salient contextual factors, including temporal sequencing and preference, influence the nature of the relationship between formal and relational contracts.

In the following sections, we theorise the risks in co-opetitive alliances and the potential for formal and relational contracting to control for such risks. We then describe our study design and provide a brief 
overview of the independent publishing sector in the United Kingdom. Finally, we present, and discuss the implications of, our empirical findings.

\section{Theoretical Development}

In this section, we first examine the risks inherent to co-opetitive alliances. We then consider formal and relational contracting as potential control solutions to manage these risks and to promote simultaneous competitive and co-operative behaviours between alliance partners.

\subsection{Risks in co-opetitive alliances}

Prior research establishes co-operation, appropriation, and co-ordination concerns as the general control challenges in inter-organisational contexts (see for example, Caglio \& Ditillo, 2008; Dekker, 2004; Gulati \& Singh, 1998; Mahama, 2006). The challenges of promoting co-operation and mitigating appropriation concerns in inter-organisational settings are referred to also as the 'relational risks' of collaboration (Das \& Teng, 1996; Schreiner et al., 2009). Co-operation between firms reflects a joint undertaking to interact for mutual benefit (Smith, Carroll \& Ashford, 1995) and necessitates a range of behaviours, including information sharing, joint problem solving, willingness to adapt to changes, and restraint from the use of power (Mahama, 2006). Appropriation concerns arise from the potential for transacting partners to behave in opportunistic ways (Dekker, 2004; Gulati \& Singh, 1998). Collaborating firms must safeguard their investments to the alliance, and secure the appropriation of value from the alliance, from these potentially opportunistic others (Dekker, 2004).

Transaction characteristics (such as asset specificity, uncertainty, and frequency) are typically used to proxy for the risks of inter-firm activity (Anderson et al., 2014), despite studies that demonstrate the effect of the broader alliance environment and characteristics of the parties to the exchange on alliance risks (Caglio \& Ditillo, 2012; Van der Meer-Kooistra \& Vosselman, 2000). Anderson et al. (2014) argue neglecting the risks of inter-firm activity that arise more broadly presents an incomplete and potentially biased perspective of the determinants of control choice. 
Despite intense interest in co-opetitive activity in the management and economics literatures there are few empirical studies that investigate specific alliance risks in this setting or relate them to observed control solutions (Fernandez, Le Roy \& Gnyawali, 2014). The potential for opportunism (relational risk) within co-opetitive alliances is noted to be of significant concern (Park \& Russo, 1996; Tidström, 2014). Competitors engaging in co-opetitive activity must co-operate in order to ensure the generation of common value for the alliance. However, there is tension between the goals of co-operation and those of each partner (Tidström, 2014). Firms acting opportunistically may use shared resources for private gain, or may delay or withdraw co-operation to the detriment of partners (Khanna, Gulati \& Nohria, 1998). Inter-firm exchanges also expose firms to the risk of transferring confidential information to competitors (Fernandez et al., 2014; Gnyawali \& Park, 2009). The potential for disparities in the division of co-created value amongst partners to co-opetitive alliances is also identified as a significant relational risk (Fernandez et al., 2014; Gnyawali, Madhavan, He \& Bengtsson, 2012), given that the partners share the same competitive goals in the market (Fernandez et al., 2014). This risk may arise from a range of sources, including the actions of potentially opportunistic partners, power imbalances between firms, or a firm's own inability to appropriate value from the alliance. Finally, partners may hold divergent strategic interests or goals in co-operating (Fernandez et al., 2014). Such differences may result in disagreements as to resource allocations or hidden agendas in relation to the misappropriation of resources from the alliance (Fernandez et al., 2014; Hamel, 1991).

In addition to the relational risks in co-opetitive alliances proposed within the management and economics literatures, Anderson et al. (2014) highlight compliance and regulatory risk as a perceived hazard across a range of alliance types. Compliance and regulatory risk is the risk that a partner to an alliance will fail to adhere to either customer requirements, firm policies, or laws and regulations, thus exposing all partners within the alliance to legal sanctions (Anderson et al., 2014). ${ }^{2}$ In co-opetitive

\footnotetext{
${ }^{2}$ Anderson et al. (2014), argue that compliance and regulatory risk is unrelated to both performance and relational risks in that it neither stems from co-ordination failures nor reflects and attempt by an alliance partner to unduly appropriate resources.
} 
contexts we expect that regulatory risk will be particularly salient, stemming from the need to navigate anti-competitive legislation. ${ }^{3}$

In general, it is argued in the literature that risks in co-opetitive contexts are more acute (Caglio \& Ditillo, 2008; Fernandez et al., 2014) because a partner who is also a competitor has a better ability to identify and assimilate information and resources that are of value to them (Cohen \& Levinthal, 1990; Park \& Russo, 1996). Thus, there is a higher risk of loss to competitive advantage and the potential for partners to become stronger competitors (Cohen \& Levinthal, 1990; Fernandez et al., 2014). Other studies, however, suggest an alternative view of alliance risks. Alliances are maintained through interdependencies (Das \& Teng, 2003). High interdependence between partners is likely to reduce the potential for opportunistic behaviour because firms have a disincentive to engage in activities that place at risk their ability to extract value from the relationship (Sambasivan, Mohamedd \& Leong, 2013). Furthermore, repeated exchanges between partners with the potential for a long-term relationship reduce the likelihood of short-term opportunism in alliances (Jap \& Anderson, 2003; Williamson, 1993). It is not clear the extent to which these relational factors mitigate the acute nature of risks between competing partners. We aim to present rich descriptions of the nature of relational risks in coopetitive contexts, allowing fuller investigation of the association between relational risks and control solutions employed.

Research Question 1: What are the alliance risks in co-opetitive alliances, arising from simultaneous co-operative and competitive behaviours between firms?

We consider next the use of control mechanisms to address alliance risks in co-opetitive settings.

\footnotetext{
${ }^{3} \mathrm{We}$ do not attempt to provide an exhaustive review of possible relational risks in this section, rather those that the literature identifies as key in co-opetitive contexts. However, our research design permits other possible relational risks to arise during the collection of empirical data.
} 


\subsection{Control in co-opetitive alliances}

The management control literature is replete with studies that examine the relation between risk and the selection of management control mechanisms in inter-firm relationships (see for example: Anderson \& Dekker, 2005; Dekker, 2004; Emsley \& Kidon, 2007; Grafton, Abernethy \& Lillis, 2011; van der MeerKooistra \& Vosselman, 2000). However, studies predominantly examine the context of dyadic buyersupplier exchanges (Caglio \& Ditillo, 2008), and focus heavily on the role of formal contracts for control, despite evidence that a wide range of control mechanisms mitigate alliance risks (Anderson, Christ, Dekker \& Sedatole, 2015; Johansson \& Siverbo, 2011). In the management and economics literatures, the concept of relational contracts (Macneil, 1974) receives much attention. Studies here examine the effectiveness of relational contracts for mitigating exchange risks, such as opportunism, in the absence of fiat. They also investigate the interplay between formal and relational contracts for effective control. In the following sections, we consider the role of both formal and relational contracts and the interaction between the two in the co-opetitive context. ${ }^{4}$

\subsubsection{Formal contracts}

Extensive empirical evidence documents the role of formal contracts for the safeguarding of assets and minimisation of losses from opportunistic behaviour (see Schepker et al., 2014 for a review) in interfirm contexts. Formal contracts mitigate relational risks by stipulating the responsibilities and obligations of each party, contingency adaptations, and legal penalties (Cao \& Lumineau, 2015; Williamson, 1985). ${ }^{5}$ Studies also investigate in an inter-firm setting roles for formal contracts beyond the control role, such as co-ordination and adaptation (the management of performance risk) (Malhotra

\footnotetext{
${ }^{4}$ We do not consider the separation of the management of competition and the management of co-operation to achieve control, whether functionally (i.e. the creation of teams dedicated to either competition or co-operation), spatially (i.e. competition in some products or markets and co-operation in others), or via the use of a third-party manager (Bengtsson \& Kock, 2000). Nor do we consider the use of equity exchange to align the interests of partners (Gulati \& Singh, 1998). Several management accounting studies provide evidence on the effectiveness of such approaches for the management of activity between competitors (see for example: Coad \& Cullen, 2006; Mouritsen \& Thrane, 2006; Thrane \& Hald, 2006; van der Meer-Kooistra \& Scapens, 2008).

${ }^{5}$ In the economics literature, the term 'formal contracts' is used to denote a range of formal control mechanisms such as performance measures, forms of monitoring and other governance mechanisms (Cau \& Luminau, 2015).
} 
\& Lumineau, 2011; Williamson, 2012). However, formal contracts are inherently incomplete (Williamson, 1979). Cao and Lumineau (2015) summarise the extant evidence relating to the limitations of incomplete contracts: they reduce the legal enforceability; they increase the risk of ambiguity and hence increase the scope for opportunistic behaviour; and they are less likely to contain adequate contingency clauses that support the flexibility of inter-firm relationships.

Studies examining the association between increased inter-firm exchange risk and the use of formal contracts offer salient insights for the control of co-opetitive alliances, in which risks are argued to be more acute. Most studies find a positive association between risks to inter-firm exchange and the use of formal controls. For example, Burkert, Ivens \& Shan (2012) find that in more complex settings, formal controls are used more intensively, while Ding, Dekker and Groot (2013) establish that, as risks increase in the transaction context, firms place more emphasis on developing more complex (inclusive and specific) contracts to manage the collaboration.

\subsubsection{Relational contracts}

Relational contracts, also termed obligational contracts or bilateral governance (Williamson, 1979), are informal self-enforcing agreements between firms, sustained by the expected value of the future relationship (Baker et al., 2002). 'The shadow of the future' (Gibbons \& Henderson, 2012: 1350) looms over these relationships, encouraging firms to adhere to relational contracts in the self-interested belief that they have a great deal to gain from continued participation and face significant losses if excluded (Chaserant, 2003; Gibbons \& Henderson, 2012).

Conceptualisations of relational contracting identified across the management control, economics, and management literatures include: trust; social relations; implicit understandings between partners; shared values and norms; sanctions; restricted membership; partner selection; flexibility; solidarity; information exchange; fairness; and informal rules, procedures and structures (Cao \& Lumineau, 2015; Dekker, 2004; Jones et al, 1997; Poppo, Zhou \& Zenger, 2008; Tomkins, 2001; Zhou \& Xu, 2012). Relational contracting reduces relational risks by safeguarding exchanges between firms. Shared values, 
group norms, and sanctions establish acceptable behaviours and the consequences of non-conformance, while information exchange provides opportunities to monitor partners' behaviours (Jones et al, 1997; Williamson, 1993). Partner selection and restricted access to the alliance reduce the scope and quantity of monitoring required of each firm (Jones et al, 1997). Few empirical studies inform our understanding as to how relational contracting may mitigate regulatory risk. However, Anderson et al. (2014) find that compliance and regulatory risk is associated primarily with informal controls, which suggests a potentially important role for relational contracting.

Despite the breadth of concepts theorised in the literature to comprise relational contracting, relatively few have received empirical attention. The majority of studies that operationalise relational contracting adopt field or survey methods and use instruments that measure only trust-related concepts to capture the construct of relational contracts (Cao \& Lumineau, 2015). Fewer studies examine multiple aspects of relational contracting and those that do examine only a small subset (Cao \& Lumineau, 2015; Schepker et al, 2014). The management and economics literatures are largely in agreement with regard to the conceptualisation of relational contracting - with one notable exception. In the management literature, trust is argued to engender confidence that transacting partners will not misappropriate (Poppo \& Zenger, 2002) and to improve the exchange of resources between partners (Morris, Kocak, \& Özer, 2007; Tidström, 2014; Uzzi, 1996). However, organisational economic approaches adopt a very different view of trust. Economic exchanges between parties are fundamentally based on a calculated assessment of expected gains and losses; as such, the notion of trust is regarded as an inappropriate analytical device for what is more accurately defined as risk-taking with a self-interest motive (Williamson, 1993). Firms employ safeguards to protect their investments from opportunistic partners and choose to behave in adherence with shared norms for self-interested reasons; employing the concept of 'trust' to explain economic exchange obscures the nature, use, and rationale underpinning such protections (Williamson, 1993). ${ }^{6}$ As such, trust is not an explanatory tool but rather an ex post

\footnotetext{
${ }^{6}$ Attempts to redefine trust into different categories, such as competency-based, calculative, etc. are regarded in the economics literature as, first, distorting the notion of trust and, second, lacking the rationale that underpins economic exchanges between firms. The use of trust in the study of economic exchanges is thus regarded as suffering from a definitional problem with too many degrees of freedom to be of conceptual value (cf. Williamson,
} 
labelling of personal affect (Barney \& Hansen, 1994). Thus, what appears to be 'trust' in such exchanges can more accurately be framed in terms of 'enlightened self-interest': a "precarious equilibrium between gain seeking and compliance with co-operation norms" (Chaserant, 2003: 172). Enlightened selfinterest encourages firms to self-regulate their behaviour in a compliant manner, thus making them appear 'trustworthy'. "[I $[\mathrm{t}$ is redundant at best and can be misleading to use the term "trust" to describe commercial exchange for which cost-effective safeguards have been devised in support of more efficient exchange....Calculative trust is a contradiction in terms." (Williamson, 1993: 463). Repeated interactions between firms provide opportunities for partners to develop an understanding of each other's operations, motivations, and likely behaviours (Gibbons \& Henderson, 2012). In a co-opetitive context, such understandings are likely to be deeper and develop more quickly because partners face identical operating conditions and deal with similar suppliers and customers. It is this understanding that develops between close partners that enables them to make informal agreements; relabelling this as 'trust' does not enhance knowledge of relational contracting (Williamson, 1993).

The different bodies of literature do agree, however, that relational contracting is an important means to supress opportunistic behaviour in inter-firm contexts, promoting co-operation in the absence of an enforceable contract (Neumann, 2010; Gil, 2009; Poppo \& Zenger, 2002; Windolph \& Moeller, 2012). Firms self-regulate because opportunistic behaviour is itself highly risky and can impact the continuation of the exchange relationship. Sanctions for opportunistic behaviour may result in fewer exchanges between parties, the termination of the relationship, and/or exclusion from future business opportunities (Carson, Madhok, \& Wu, 2006; Chaserant, 2003; Gibbons \& Henderson, 2012). The threat of sanctions is particularly pertinent in co-opetitive contexts in which reputational concerns may harm a firm's ability to build vital relationships with competitors.

Relational contracting is a time-consuming and inherently fragile process, reliant on the shared interests of partners and their ability to develop implicit understandings (Cao \& Lumineau, 2015). Despite this, 
in complex inter-firm contexts, where formal contracts can be prohibitively costly to write, relational contracting can overcome the need to contractually specify future business needs (Baker et al., 2002; Schepker et al., 2014). Regular communication between partners enables them to understand the basis on which promises are made to each other and hence to make realistic, or credible, commitments (Gibbons \& Henderson, 2012; Williamson, 1993). Credible commitments reflect the calculus of gains and losses, but must also offer sufficient flexibility to adapt to unforeseen circumstances (Jones et al, 1997; Williamson, 2008). There is little evidence for the association between increased alliance risks and the use of relational contracts, but high interdependence and repeated exchanges between partners are argued to signal a greater role for relational contracts (Jap \& Anderson, 2003; Williamson, 1993).

\subsubsection{Formal and relational contracts as substitutes and complements}

A large number of studies question the relationship between formal and relational contracts for the management of alliance risks between firms (see for example Cao \& Lumineau, 2015; Li, Xie, Teo \& Peng, 2010; Malhotra \& Lumineau, 2011; Poppo \& Zenger, 2002; and Schepker et al., 2014). Studies supporting a substitutory relationship argue that firms invest in the development of relational contracts only where transactional attributes render the cost of formal contracting prohibitive. And conversely, where relational contracts are well developed, formal contracts are potentially damaging to relational contracts and redundant at best (Cao \& Lumineau, 2015; Malhotra \& Lumineau, 2011; Williamson, 1993). However, some studies suggest that investments in relational contracts are unrelated to transactional attributes (relational risks) (Schepker et al., 2014). As complements, formal and relational contracts are argued to be mutually reinforcing. Formal contracts signal an intention to co-operate that facilitates the development of relational contracts (Cao \& Lumineau, 2015), and relational contracts can foster continuation of formal contracts in the face of change or conflict (Poppo \& Zenger, 2002). In a meta-analysis of existing literature, Cao and Lumineau (2015) find strong evidence of complementarities between formal and relational contracts but conclude that the interplay between formal and relational contracts is context specific. Factors that affect this relation include the exchange hazards or risks inherent in different types of inter-firm relationships (Cao \& Lumineau, 2015), temporal 
factors (Huber, Fischer, Dibbern \& Hirschheim, 2013), as well as firms' preferences for the use of either formal or relational contracts (Bolton, Malmrose \& Ouchi, 1994; Li et al., 2010). The impact of these influences on the relative use of formal and relational contracts in co-opetitive contexts is unclear.

In summary, we seek to understand better how alliance risks in co-opetitive settings influence the use of formal and relational contracts. We also aim to investigate the interplay between the two. Few studies consider the nature of the contracts selected and how these address specific alliance risks.

Research Question 2: What are the roles of formal contracts and relational contracts for the control of co-opetitive alliances? What is the relation between formal contracts and relational contracts in this setting?

\section{Research Design}

We conducted our study in the independent trade publishing sector in the United Kingdom, a setting in which firms conspicuously engage in co-opetitive activities. ${ }^{7}$ We employ field-based research methods in order to capture rich evidence of the relational risks and the associated governance mechanisms in this setting, thus responding to recent calls for qualitative evidence in the area of relational contracting (for example, Cao \& Lumineau, 2015). Our study investigates a sales alliance between six independent publishing houses that together account for almost half of the trade publishing volumes in the independent sector (Tivnan \& Lewis, 2015a). We conducted our study in this particular alliance because it is a complex setting involving both vertical and horizontal collaborations in which both formal and informal agreements between firms are evident. We collect data from each of the six publishing houses. This plurality of viewpoints enables us to obtain a comprehensive picture of the relational risks and governance of the alliance (Caglio \& Ditillo, 2008; Dekker, 2015). Brief descriptions of each of these

\footnotetext{
${ }^{7}$ Trade publishing focuses on the production of fiction and non-fiction titles for consumption by the general public. The other main sectors within the publishing industry include: educational publishing; academic publishing; and reference publishing (e.g. dictionaries and encyclopaedias) (Germano, 2008). Typically, classification of a publisher reflects the genre that forms the majority of their output.
} 
firms, which we refer to using the pseudonyms Austen, Brontë, Carroll, Dickens, Eliot, and Gaskell, are included in Appendix $1 .^{8}$

The sales alliance entails both 'horizontal' activities between competing partners, aimed at increasing book sales and securing promotional opportunities with key booksellers, as well 'vertical' buyersupplier arrangements. In addition to the sales alliance, we also collected data on various other interfirm activities including the group purchasing of printing services and the outsourcing of production services. Outsourcing of production services involves a 'vertical' relationship in which one firm provides third-party services to another, smaller, firm. Group purchasing of printing services is a 'horizontal' activity in which the firms pool resources in order to obtain economies of scale in printing volumes. The sales alliance is the focus of this paper as the most strategically important and complex of the alliances in which the firms are involved, and thus provides the basis for addressing our research questions. While we do not include a full analysis of the risks and associated governance mechanisms in the other alliances we do draw on data from these other alliances to demonstrate how attributes of relational contracting may be deployed across multiple alliances with common membership. ${ }^{9}$ We depict the alliances studied in Figure 1.

[Insert Figure 1 here]

We analyse data gathered from 26 semi-structured interviews with 21 participants, including the managing director of each publishing house and sales directors from three of the firms. ${ }^{10}$ A list of all participants interviewed in the study is included in Appendix 1. Interviews ranged in time from fortyfive minutes to one and a quarter hours, averaging one hour in duration. We asked participants to reflect

\footnotetext{
${ }^{8}$ We also collect data from a seventh publishing house, Hardy, included in Appendix 1. Hardy is not a member of the sales alliance; it is a member of the third-party production alliance with Brontë.

${ }^{9}$ We include a summary of observed mechanisms of relational contracting for the third-party production and printing alliances in Appendix 2.

${ }^{10}$ We conducted our first interviews at Brontë, where we interviewed the managing director and each of his five functional specialists. During our interviews with these five individuals, it became apparent that their direct involvement in collaborations with competitor firms was minimal. In our visits to the remaining firms, we therefore conducted interviews with the managing directors of these firms and any staff they identified as having substantive involvement in collaborations with competitor firms. We use interview data collected from suppliers and customers to the alliance to validate the contextual industry and market data provided by the publishers.
} 
on the rationale for co-opetitive activity, alliance risks, and the control mechanisms employed. We used an interview guide to ensure that we covered all relevant themes in each interview and to help minimise the potential for interviewer-induced bias (Minichiello, Aroni, Timewell, \& Alexander, 1995). The interviews were audio-recorded and then transcribed verbatim (McCracken, 1988). We also collected a range of archival documents. Documents include company and industry publications such as operating reports, industry and company outlooks and histories, press releases, and financial statements. We referred to data from these various sources to construct the descriptions of the independent trade publishing sector and each publishing house that are presented in Appendix 1. We were unable to collect any archival documents that specifically relate to the 'collaborations'. There is no publically available information, and commercial sensitivities precluded the firms from permitting us to retain copies of formal contracts and other internal documents.

Both authors coded the interview data using the software package NVIVO. As coding reflects the association of text with one or more broad themes of interest, inter-coder reliability between researchers was high. We uncovered a small number of minor exceptions, which we resolved through further discussion. NVIVO search and retrieval tools permitted the text in the transcripts to be reorganised and reported back under the various themes of interest identified in the coding schema. Using the reorganised transcripts, we then systematically analysed each key theme (Miles \& Huberman, 1994). We created summaries of key themes for each interviewee that included quotations from the interview transcripts as well as memos created by the authors that reflected some data interpretation and analysis. These summaries form the basis of the findings presented in this paper.

\section{The Independent Publishing Sector in the United Kingdom and the Sales Alliance}

A large number of independent publishing houses together with small conglomerates account for 40 per cent of trade publishing turnover in the United Kingdom. The top ten conglomerate publishing firms 
account for the remainder (Tivnan \& Lewis, 2015a; 2015b). ${ }^{11}$ The commercial success of all trade publishers is dependent on their ability to purchase or commission book titles that will sell in large volumes to bookshops and other booksellers, such as supermarkets and online sellers. Significant pressures on profit margins extend across the value chain. Publishers make advanced payments to authors, some years ahead of the publication date, but sell to booksellers on a consignment basis. The purchasing power of the major booksellers places further pressures on publishing firms with smaller book lists and fewer commercial book titles. Further, there is significant uncertainty surrounding the performance of any given publication. Innocuous titles may become best-sellers while expected successes can fail. Pressures on all aspects of the publishing process create financial incentives for the independent publishers in our study to collaborate.

The sales alliance, the main focus of our study, involves all the firms in our study. Brontë, Carroll, Dickens, Eliot and Gaskell, small firms each with less than 30 employees, outsource part of their sales function to Austen. Austen, the largest publishing house in this study, retains an in-house sales force that visits booksellers around the country with the aim of securing orders for new book titles. Prior to using the sales function at Austen all purchasing firms contracted with specialist sales organisations (that are not publishing houses) for these services. A number of collaborative imperatives for the sales alliance are apparent. First, the large numbers of publishers in the industry and the relative power of booksellers render access to potential customers increasingly difficult for any firm acting alone. Through collaboration in the sales alliance, this group of publishers creates a combined book list of the scale and quality required to improve access to booksellers. This level of access was not attained through their previous relationships with specialist sales organisations. Second, the purchasing firms lack the financial resources to establish and maintain their own in-house sales function, while Austen, the largest independent firm in our study, acquires a stable revenue stream to support its operations.

\footnotetext{
${ }^{11}$ Conglomerate organisations operate a number of different businesses, of which publishing is just one element. They are regarded as constituting a separate sector within the publishing industry due to fundamental differences in their nature, structures, and strategic objectives.
} 
The members of the sales alliance also undertake joint marketing activities in an effort to advance the promotional opportunities for book titles published by members to the alliance. Thus, the alliance involves both vertical (outsourcing) as well as horizontal (group collaboration) activities. These activities require the firms to work closely and repeatedly together to derive the benefits available through collaboration.

In the remainder of the paper, we present and discuss the empirical findings of an investigation into the management and control of co-opetitive activity between six independent publishing houses in the United Kingdom.

\section{Co-opetition and Control in the Sales Alliance}

We begin this section by describing the co-opetitive nature of the relationship between the firms. We then examine the alliance risks that arise between the independent publishing houses before analysing the role of formal and relational contracting for the control of these risks.

\subsection{The nature of co-opetition}

The firms in our study regard themselves as keen competitors in the area of sales, competing directly for orders from booksellers.

"[T] here is no disguising [the competition between us] and everyone within the [alliance] knows that, it's the basis on which we conduct all our business." (Managing Director, Gaskell)

Competition in sales for orders from booksellers manifests in each firm's choice of the format, style, cover design, author, and title of each book, and the speed at which books are printed and distributed.

"The supermarkets... they choose by cover really, more than anything else, so they would go for the most successful commercial-looking cover." (Managing Director, Carroll) 
The partners recognise that in joining the alliance and outsourcing sales to Austen, they also all compete for the attention of Austen's salesforce to promote their books over their competitors.

\begin{abstract}
"Where we're competitive is that our team here needs to make sure that they hound Austen as much as possible...[W] 've got to make sure that we give them all the ammunition they need in order to do that, so how I target everything at [Carroll] is that we've always got to be better than our competitors [in the alliance] with the information we provide, with the marketing materials we provide and with the publicity as well and then the quality of the books...I'm competing against Austen getting it out of the bag." (Sales Director, Carroll)
\end{abstract}

However, co-operation in the sales alliance brings many benefits to the firms. Most importantly, by working together the firms secure access to booksellers.

"[T] he root of collaboration is: collectively we are stronger ... in dealing with reluctant partners, like large retailers. When they see all our books for a season fanned out together, [they] find us the best list." (Managing Director, Carroll)

"[M] any of the people round the table can't ever forget that they wouldn't even have the conversation with the retailer if they were not [in the sales alliance]." (Managing Director, Eliot)

"[I]t's collaborative, it's separate houses coming together to share skills and [improve] access [to booksellers] and you have to forego a certain control, which you would have if you were dealing with [major bookseller] direct." (Managing Director, Gaskell)

The firms also engage in co-operative activities to improve their access to the limited promotional opportunities offered by booksellers. Collectively, the firms generate far greater opportunities for the alliance than would be possible by each firm acting on its own. However, the firms must then compete for the opportunities they jointly create. For example, the firms must reach agreement as to the book titles from the alliance's collective list that will receive the 'promotional slots' awarded by supermarket chains to the alliance and reap the associated sales orders.

“We are competing for a finite amount of shelf space and promotional slots." (Managing Director, Dickens)

"One or two of the supermarkets said to the [sales alliance] 'you have two slots a month.' So the lucky publishers will print and the [supermarkets] would order a minimum of 10,000 copies...So there we are competing immediately and directly against all the other companies in the [alliance] .... But without the [sales alliance] you wouldn't have any slots at all. So you have two to share...rather than none on your own." (Managing Director, Carroll) 
The firms base their collective decision solely on the book title that is likely to have the greatest massmarket appeal and will therefore generate a high level of sales, thus enhancing the alliance's reputation. The benefits that accrue to the firm in receipt of a promotional slot motivates all firms to co-operate in this activity, despite the knowledge that the slots are not shared equally.

'It's not democratic, you don't say 'well you had it last month' 'cause that's not how it works with the supermarkets." (Managing Director, Carroll)

The firms also collaborate in other sales and marketing activities. For example, when jointly publicising new book titles the firms informally agree which books will be included in any communication, the third-party agency employed to organise associated events, as well as the format, wording, and date of the press release. Similar processes are used to support partners in their individual business activities. For example, a firm may delay a planned book launch to ensure it does not interfere with that of another partner to the alliance. The firms also co-operate by sharing information, skills and expertise that shape both their individual and joint activities. Co-operation requires the firms to work closely and repeatedly together to exploit the benefits available to them. They face continual pressures to navigate the cooperative and competitive tensions that stem from working together.

"[E] ach of us are very proud of our own independence and so there are both centrifugal and centripetal forces in the alliance 'cause we want to do our own thing as well as doing things together... [F]or example we'd all rather speak to the media and see our own companies represented in the media than simply the [sales alliance]." (Managing Director, Carroll)

\subsection{Alliance risks}

We identify a variety of risks in the sales alliance, stemming from both the vertical (outsourcing to Austen) and horizontal joint activities of the sales alliance. Relational risks are apparent in the outsourcing activities where each firm recognises the potential for Austen to misappropriate information gained during the course of inter-firm exchanges. Austen obtains insights into its competitors' strategies and, specifically, access to pre-publication information relating to each new book title. As a 
publisher itself, Austen could readily identify and incorporate valuable aspects of this commercially sensitive information into their own publication processes.

"II]fyou're developing a list of titles with a particular thread running through it, or you're trying to hit a particular market with a particular type of book in terms of format, trying to develop something you thought was new, how do you protect a partner from taking that away from you?" (Managing Director, Eliot)

The outsourcing firms also recognise the scope and motivation for Austen to behave opportunistically. For example, Austen's partners express concerns as to whether their book titles receive equal prominence and attention by sales people during pitches to booksellers.

"[I]f I was [Austen] I would want my sales people to get my books out of the bag first; it's just human nature, and you accept that." (Managing Director, Eliot)

"The big downside; ...we were the first out of the bag for [previous sales organisation], we won't be for Austen. And so that's a problem." (Managing Director, Brontë)

Similarly, Austen has both the capacity and incentive to delay informing its partners about forthcoming discussions with major booksellers, or could even withhold such information altogether. Austen could also undermine its competitors' sales activities by, for example, speeding up or delaying certain aspects of the process. As the larger partner in the alliance, Austen could potentially also use its size to obtain unfair advantages, for example, in contractual negotiations with each partner. While we find no evidence of opportunistic behaviour by Austen, its partners highlight that there is a higher level of risk associated with outsourcing to Austen, a direct competitor, which did not arise in their previous relationships with specialist sales organisations.

"It clearly does not give you a sales advantage to be dependent on [Austen's] salesforce because, of course, if you have two not dissimilar titles, which one are they going to promote first? On us they take commission, on theirs they take a full publishing profit." (Managing Director, Carroll)

However, Austen's incentive to exploit its size and unique role is reduced through its dependence on the other firms, recognised on both sides of the buyer-supplier relationship. This belief in the long-term benefits of collaboration to Austen mitigates the risk perceived by its partners. 
"As a salesperson, you sell what you can sell. So I think the risk [for our partners] is tiny, and the benefits are enormous. [W] e earn good commission, and, you know, we push literature and poetry and drama, it's hard to make money out of some of what we do.... [S]o in terms of scaling down our costs, and recovering them ... to be able to afford that is really good news." (Managing Director, Austen)

"They need us, because we can amortise quite a lot of their sales overhead...there's quite a lot of upside in it for them." (Managing Director, Brontë)

In relation to the 'horizontal' activities of the alliance, firms acknowledge that they are exposed to the risks of opportunistic behaviour from all partners, not just Austen. For example, any firm could attempt to establish covertly a relationship with a bookseller that might provide them with an advantage over their partners.

"[A]n exclusive deal with a retailer on the part of one of the houses that in some way impeded, grossly impeded, the activities of the other houses at that time... a sort of exclusive arrangement that was for short term commercial gain but necessarily at the expense of everyone else, that would be the kind of thing that would be very, very destructive." (Managing Director, Gaskell)

Similarly, knowledge of a firm's marketing strategies could enable a partner to sabotage a competitor's book launch by releasing in advance a competing book title, while collaboration in joint marketing activities exposes firms to the risk that a partner may choose or need to delay the process.

"To maximize the P[ublic] R[elations] potential, the press release does [need to go out on Monday]. If I was being entirely selfish I would say, no, it's got to go out on Monday, and, for [Managing Director of Carroll], it's too bad." (Managing Director, Dickens)

Thus, firms have various opportunities to behave in ways that would undermine a partner - and occasionally succumb to such temptations.

"I did a rather naughty thing...some of my colleagues weren't that thrilled. I probably should have asked them but if I'd asked them they'd have said no..." (Managing Director, Brontë)

Furthermore, firms attempt to manage carefully discussions about forthcoming book titles and marketing strategies in order to ensure that they do not accidentally release information beyond that required to support the collaboration. 
"The whole protection of intellectual property was as much a concern for us as anyone else. ... There are lots of concerns about working with another publisher." (Managing Director, Eliot)

Our data revealed a unique type of relational risk that can arise in alliances between competing partners. While acknowledging the need for close co-operation, the firms are anxious to maintain their independence, an important element of which includes protecting their individual identities and competitive positioning.

"The thing that mustn't be shared, in any way, is...the actual process by which books get to be [commissioned by a publishing house], how they look, how they are shaped... The individual personality of the company mustn't be shared; it would be a disaster." (Managing Director, Austen)

They express concern that inclusion in the same 'sales bag' as their competitors could engender increased homogeneity between their product offerings through unwitting imitation. The firms are aware that participation in the sales alliance heightens the potential for convergence between their identities and product offerings over time as they share details of each other's products and marketing strategies.

Finally, we find that partners to the alliance are also particularly vigilant to the risk of actual or perceived anti-competitive behaviour arising from co-operative activity with their competitors. The firms acknowledge the need to ensure they do not breach legislative requirements relating to collusion, for example, in price fixing.

"[W]e are in the business of looking at ways of collaborating...Obviously not being anti-competitive or anything like that...[W]e can't talk about pricing or terms of trade, all that kind of stuff." (Managing Director, Brontë)

In the following sections, we explore the use of formal and relational contracting in managing the relational risks related to concerns about misappropriation, opportunistic behaviour, and homogeneity and those related to anti-competitive behaviour. 


\subsection{The role of formal contracting within the sales alliance}

In relation to the outsourcing activities of the alliance, each firm maintains an individual contract with Austen. This standard contract specifies the annual fee and commission rate payable to Austen. It also includes the obligations on each party in relation to the operational aspects of the sales process, mutually agreed targets, and the timely provision of manuscripts, inspection copies, and pre-publication information about each book title.

Despite the explicit and highly measurable nature of the sales process, and the risks associated with passing this activity to a close competitor, the contract does not include any specific, formally monitored performance measures for Austen. The firms acknowledge the challenges involved in contracting for performance in the high uncertainty environment of book publishing.

"[We might not reach our sales targets] 'cause we published the book late, because the cover was bad, because the author didn't do the publicity they were promising, because the reviews were terrible. There is no way of knowing. [Austen] may do a great job and the book still disappoints or they may do very little and then it slowly takes off." (Managing Director, Carroll)

The formal contracts are seldom used to manage any aspect of the relationship between Austen and each firm, with managing directors believing that to do so may in fact damage inter-firm co-operation.

"I've never known anyone bring contractual points to bear on a business relationship...People will often halfway down the line scratch their head and go, 'What did we say in the contract?' We almost use it as a mutual reference point, as to how they should resolve the situation... publishing has a reputation of being gentlemanly, and it tends to be." (Managing Director, Dickens)

Instead, the contracts are used primarily for the purpose of managing performance risk: to plan and coordinate the requirements of each firm in relation to the activities of the salesforce. The contracts are standard for the industry and details are mutually determined by both sides to the agreement.

"[The contract] just says that there are obligations on both sides to keep each other up to date on what's going on. It isn't more detailed than that." (Sales Director, Carroll)

"[I]t's like a relay race, you know, if your hand goes out and if nothing goes in it, you start getting cross, and saying... where is it? [Dates and other requirements are] extremely formally specified, absolutely clear, completely clear, rigorously clear." (Managing Director, Austen) 
While Austen, as the provider, is responsible for managing and co-ordinating the sales process, we found no evidence that they were dictating the terms of each contract, and, in fact, their reliance on the revenue stream from the alliance reduces their incentive to do so.

The contracts between Austen and each of its partners also include standard confidentiality clauses. While the firms acknowledge that Austen could misappropriate information from buyer-supplier activities for its own internal purposes, these clauses are designed to mitigate the risk that Austen might pass planned and actual sales information onto to another partner in the alliance (regulatory risks of buyer-supplier activities).

Notably, sales to the centralised purchasing offices at the major booksellers, accounting for 40 to 50 percent of each firm's turnover, remain within the control of the individual firms. By removing Austen's access to these key accounts, the firms eliminate the risk that Austen's salesforce will offer its own books to this important customer group before those of its partners. However, this does not entirely mitigate the risk that Austen could behave opportunistically. For example, Austen's detailed knowledge of its partners' activities means that it can speed up its production of a similar book or copy elements of a partner's marketing strategy.

Either Austen or the purchasing firm, subject to a set notice period, can end the contract. Each contract between Austen and a purchasing firm is separate and is not dependent on the existence or terms of any other contract in the alliance. Similarly, there is no formal contract between all partners to govern the broader horizontal activities of the alliance. The alliance partners deliberately eschew the use of a formal binding agreement or other formal outcome mechanisms as they regard the precise nature of the various horizontal activities and the requisite behaviours as difficult to specify ex ante and hence expensive to contract.

\footnotetext{
"No contracts, [just a] gentlemen's agreement...because every time we get into a strata of detail we incur very large costs and we create huge problems... We have a whole raft of letters of agreement, they are generated in-house but are pretty clear and good and thorough and they're perfectly sufficient. [Y] ou need some agreement about feedback and monitoring on a quarterly basis,...has anyone misbehaved?" (Managing Director, Brontë)
} 
As well as deciding against the use of a contract to manage the sales alliance, the firms in our study have also considered and rejected the idea of formal structures such as governance authorities.

"[T] here has often been a question should there be any kind of executive, a constitution that governs us and all of that, and there's no appetite for it...[A]nd why, I think 'cause the thing works." (Managing Director, Austen)

Despite the absence of formal contracts or governance mechanisms to manage the broader horizontal activities of the alliance, we find that the individual contracts between Austen and each of its partners, designed for buyer-supplier activities, exert an indirect influence on the horizontal relationships between the firms. The standard confidentiality clauses in these contracts ensure that a partner's proprietary information remains between Austen and the firm. Thus, adherence to the confidentiality clauses in individual contracts implicitly restricts the proprietary information that can be known widely between the alliance partners and used in relation to other sales and marketing activities.

"Each of us observes each other's commercial confidentiality. So I genuinely do not know what the other contracts are." (Managing Director, Carroll)

By strictly adhering to confidentiality clauses in their contracts with Austen, the firms also reduce the risk of accusations of anti-competitive behaviour in relation to their horizontal activities, for example, in relation to price-fixing. Austen, as the supplier to each of the other firms, is particularly alert to activities that could be construed as either opportunistic or anti-competitive.

"[O]ne must always be mindful that you can't put those people in the room to discuss commercial matters of the individual businesses." (Managing Director, Austen)

\subsection{The role of relational contracting within the sales alliance}

The firms rely heavily on relational contracting to mitigate the risks associated with the joint activities that constitute the sales alliance. Both the vertical and the horizontal activities are governed primarily through the use of informal agreements (relational contracts). In this section, we discuss the specific 
contracting mechanisms evident within the sales alliance. We pay attention to the ways in which these mechanisms work to mitigate particular relational risks.

Common membership of an industry guild and prior employment at conglomerate publishing houses have created social ties between the firms that provide the basis for selecting partners with similar objectives and values.

"[W] hen [managing director Austen] arrived at Austen and became the managing director and asked me to go there with the Carroll sales, I immediately said yes. I did that. So we do have a long standing relationship..." (Managing Director, Carroll)

In forming the alliance, the firms have collectively developed an explicitly stated set of values to which all partners are expected to subscribe. ${ }^{12}$ The firms acknowledge the strength of the social ties between them, and articulate the importance of supporting the unique character of each firm as a central shared value.

"I think there are very strong ties.” (Managing Director, Eliot)

"We want each of these companies to be so distinct and innovative. The sympathy is all about the notion that you have the freedom to be yourself." (Managing Director, Austen)

Implicit values, such as expressions of solidarity towards partner firms, are also evident in the alliance.

"[The group] is very, very important for solidarity... it is quite an isolated task and you wonder what other people are doing and want to know that other people are doing the same thing as you." (Managing Director, Carroll)

The values that characterise the alliance mitigate relational risks between firms in several ways. First, by demonstrating commitment to the values a firm can signal to its partners its intention to engage in co-operative behaviours and, by implication, to abstain from opportunistic actions. Second, the values

\footnotetext{
${ }^{12} \mathrm{We}$ are unable to list these explicit values due to the risk that this will identify the alliance and its member firms.
} 
help mitigate the risk of homogeneity between firm product offerings by providing an explicit reminder of the shared belief in the value of diversity in product offerings.

In addition to the values articulated by the partners, the alliance seeks to promote norms of behaviour (codes of conduct) between firms. These behavioural norms set out a framework of expectations between firms in the alliance that would not normally be extended to other competitors in the publishing industry. For example, the firms have an implicit understanding that they will not 'poach' human capital from each other.

“[T] here are basic rules...they're not formal and they've never been specifically articulated but there is a presumption against poaching each other's staff and authors, which we're generally very willing to do in publishing." (Managing Director, Carroll)

Compliance with these behavioural norms requires self-restraint by each firm. As with the shared values, the exercise of restraint serves to demonstrate each firm's commitment to the alliance, and plays an important role in sustaining the informal agreements between firms. Self-regulating behaviours by the firms are apparent in both the horizontal and the vertical activities.

[T] here is no written constitution or appeals process and arbitration. No, it's much more about building up trust and relationships... and not behaving badly." (Managing Director, Carroll)

"I think that we've always had a very high level of trust with Austen as an organisation keeping those Chinese walls in place... 'cause they have access to a lot of our sales information." (Managing Director, Eliot)

However, reliance on the self-restraint of partners exposes each firm to the risk of opportunistic behaviour. We find that informal gatherings and attendance at meetings provide firms with opportunities to monitor that their partners continue to act in expected ways.

"[Positive behaviours] reinforce trust in terms of ongoing collaborations...Each of us individually would subscribe to those values... but perhaps in the sense of there being other people watching you, you're doubly minded to uphold those values." (Managing Director, Gaskell) 
Meetings and informal gatherings between any combination of the firms facilitate the flow of information. In particular, reputational information about each other and other firms in the industry helps to safeguard exchanges between the partners.

"We share information, we share gossip, and that gossip's incredibly important." (Managing Director, Brontë)

For example, the Managing Director at Brontë indicated the importance of reputational information in informing his decision to select Austen as his outsourcing partner.

"Carroll, who are very good friends of ours, who are only a mile up the road - I meet their Managing Director for coffee every now and again - they were delighted with [the service from Austen]." (Managing Director, Brontë)

Meetings between firms are also important in creating a sense of solidarity among partner firms in ways that promote collaborative rather than opportunistic behaviours.

"[Our meetings] reinforce the sense of togetherness, common goals, common threats, and the desire to work together to mitigate those threats." (Managing Director, Gaskell)

Regular meetings also enable the outsourcing firms to monitor Austen's behaviours and commitment to the vertical, buyer-supplier, activities within the alliance. Any concerns about Austen's behaviour or performance are evaluated within the uncertainty of the sales process and the overall benefits of the arrangement.

"[I] treally is a fine balance between beating the [salesforce] up, getting really cross, and then going back to them a week later and saying, 'So, here's our new books, would you like to submit these as well?' with a smile on your face...We've just had [author] published...The supermarkets have turned it down. We are disappointed, but we have to believe that Austen did the best job for that [title]. I've got no other way to get to a supermarket without them." (Sales Director, Carroll)

While meetings and gatherings between firms are themselves an important relational contracting mechanism they also further expose firms to alliance risks, particularly given their in-depth understanding of each other's business. Thus, this mechanism is a 'double-edged sword' in both 
creating alliance risks while simultaneously mitigating them via the monitoring opportunities meetings provide.

Despite the various relational contracting mechanisms in place, opportunistic behaviours have occurred in the past. One managing director admitted to a minor misdemeanour and acknowledged that he would not repeat such behaviour, knowing it to be against the accepted norms.

“I won't do it again...[I]t wasn't very collegial.” (Managing Director)

Adherence to the shared values and the 'rules' of conduct they imply is an expectation of continued involvement in collaborative activity. Any firm that unilaterally pursues its own agenda to the detriment of the sales alliance faces an implicit threat of sanctions from all partners that may jeopardise its participation in current or future collaborative activities.

“[Firm] transgressed... But it's a generous group and we said 'you've had your wrist slapped, we'll put up with it, but don't do it again'." (Managing Director, Austen)

We find much evidence of the firms' willingness to restrain from opportunistic behaviour in order to protect their membership of the alliance. For example, despite being the largest firm in the alliance, Austen has a strong motivation to behave in accordance with the norms of the group because it is mutually dependent on its partners for both access to booksellers and the financial benefits available from collaboration.

\footnotetext{
“We have to be trusted to look after everyone's interests, at the very least at the same amount as Austen... [W] hen we sell [best selling book title] by [author] from [another publishing house], it's coming out of the bag first, because if I'm a sales person and I've got call to make, I want them to feel good about me before I've even begun ... [the Managing Director of Dickens and Managing Director of Brontë] say to me explicitly 'this damn thing wouldn't work if you weren't so generous.' And they mean it...I see it as smart capitalism." (Managing Director, Austen)
}

Similarly, the Managing Director of Carroll explained how he might agree to delay a planned book launch to ensure it did not interfere with that of a partner to the alliance. 
“Austen [might] say 'Well, [sales alliance competitor]'s got this book coming out in November, they can't move [the launch] because they're bringing out the author from Australia...don't you think you should move yours to October or December?" (Managing Director, Carroll)

Examples of self-regulating behaviour are also evident in mitigating the risks associated with homogeneity in product offerings and anti-competitive behaviours.

"I]t's very beneficial to see, oh, well [another member firm] is doing a huge marketing campaign for that...[W] e always try to be different to them as well." (Sales Director, Carroll)

"[Our meetings help us] to share information, to share knowledge, to share experiences. Always without numbers attached so as not to breach any commercial, legal borders." (Managing Director, Gaskell)

The firms are aware that acting unilaterally for short-term gains places at risk their continued involvement in collaborative activities. By demonstrating self-restraint, a firm provides assurance to its partners of its commitment to the alliance, thus reducing the need for constant monitoring or formal agreements.

"If I did a thing like that [send a press release before securing agreement from our partners], we would never be in this position anyway, because no-one would want to deal with someone like that... That is just not the spirit in which this [alliance] works." (Managing Director, Dickens)

The informal agreements between the firms enable partners to make individual decisions about which activities of the sales alliance to join, based on the perceived value to their business.

"[T] here are bilateral and trilateral set-ups within the [alliance] as well. In fact,...there's almost nothing we all do at the same time. Everyone has opt-ins and opt-outs... Nobody has ever done anything that harms their business for the greater good of the sales alliance, not once, and we wouldn't either. " (Managing Director, Brontë)

These arrangements provide the firms with assurance that a partner whose objectives are no longer aligned with the other firms can leave the alliance rather than being forced to remain, potentially exposing the group to opportunistic behaviours. Flexibility in arrangements between firms is important for sustaining the informal agreements between the firms. 
"I want to be sure that everyone is in for the long-term...to be clear about whether there is a risk to us of someone pulling out. But there has to be some flexibility...I mean, you need to allow for people to change their mind on very reasonable grounds. "They [might leave if ] ...being a member of the alliance was not aligned with their business aims." (Managing Director, Austen)

The firms thus recognize that the continuation of the alliance depends on demonstrable benefits to each firm beyond those attainable by working alone or with other firms. Self-interest is the key motivation for continued participation.

"[T]hey see the strength in success for the alliance is success for them so [it's] enlightened self-interest." (Managing Director, Austen)

"[W] can only collaborate if it's in everyone's self-interest. We have tried to do things 'cause they will be nice to do... but it doesn't work...There's just not enough upside... We can only act together when the stakes are very, very high." (Managing Director, Brontë)

In summary, we observe a range of relational contracting mechanisms in the sales alliance that mitigate the relational risks within the alliance and permit reliance on informal agreements (relational contracts). Observed mechanisms include shared values, an implicit understanding as to appropriate behavioural norms, alliance meetings and informal gatherings, and the threat of sanctions. Notably, we observe these same mechanisms in other alliances these managing directors have established, such as the printing alliance and third-party production alliance. ${ }^{13}$ Our findings suggest that these mechanisms work by reinforcing the notion that commitment to the alliance is likely to be more beneficial in the long-term to each partner than are opportunistic behaviours. Firms' acceptance of the long-term benefits of the alliance encourages them to engage in light-touch but perceptible monitoring of each other, and informs their selection of partners who are willing to subscribe to the same values. The evidence suggests that social ties, self-regulating behaviour, flexibility, and enlightened self-interest support these mechanisms in ways that enable the firms to make and keep informal agreements (relational contracts).

\footnotetext{
${ }^{13}$ While space constraints prevent us from explaining in detail each of these other alliances, Appendix 2 provides summary evidence of risks and relational contracting in the other alliances in which these firms participate. Our analyses of the third-party production and printing alliances revealed no different types of risks and no notable differences to the use of formal and relational contracts to those identified in the sales alliance. We draw on our findings of the other alliances to demonstrate that the nature and use of relational contracting is not unique to the sales alliance.
} 


\section{Discussion of Findings}

In this section, we draw on our empirical findings to examine the role of formal and relational contracts in managing alliance risks in co-opetitive settings. We also consider the interplay between formal and relational contracts.

\subsection{Alliance risks in co-opetitive alliances}

The firms in the alliance acknowledge the potential for misappropriation and opportunism as key concerns because, as close competitors, each firm can identify and readily exploit information gleaned from shared activities. In relation to the outsourcing relationship with Austen, the purchasing firms acknowledge various ways in which Austen can misappropriate resources (for example, using purchasing firms' pre-publication information to improve their own product offerings) as well as the scope for Austen to act opportunistically (for example, by 'getting their book out of the bag first'). Further, firms acknowledge that the horizontal activities of the sales alliance expose them to potential opportunistic behaviour from all competing partners in the alliance, not just Austen (for example, all firms to the alliance can misappropriate product information that can readily be used to improve their own competitive position). Firms acknowledge that departures from co-operative behaviours, by Austen and other partners, have the potential to significantly impact their competitive advantage. The partners' concerns thus appear consistent with prior claims in the literature that relational risks will be more acute in co-opetitive contexts (for example, Caglio \& Ditillo, 2008; Fernandez et al., 2014). In fact we find little evidence of, or appetite for, opportunistic behaviours. Rather, our findings support arguments that dependence and repeated exchanges between partners can reduce opportunistic behaviours because any firm that behaves against the norms of the group potentially faces the threat of exclusion from other collaborative activities crucial to their survival as an independent publisher (for example, reduced access to booksellers) (cf. Jap \& Anderson, 2003; Williamson, 1993). Furthermore, in the context of a co-opetitive alliance, while firms have a greater capacity to act opportunistically, they also have a keener ability to identify opportunistic behaviour by their partners. They also have a strong motivation to 
identify such behaviours. In line with prior suggestions (for example Chaserant, 2003), we find that the expectation that opportunistic behaviour will be readily identified by partners further reduces the likelihood that any firm will engage in such behaviours. Our findings thus extend prior literature to demonstrate that, while relational risks between competitors may appear to be more acute, the nature of the co-opetitive context simultaneously acts to mitigate these concerns. Furthermore, consistent with Neumann (2010), we find that firms with a natural advantage, such as larger size, may restrain from using their power because of the perceived benefits that arise from the alliance. Austen's size potentially increases its ability to act opportunistically in the role of supplier to the other firms but such behaviours could affect its long-term ability to extract gains from the alliance that it needs to support its activities.

Our co-opetitive setting also enables us to identify an additional type of relational risk unique to competing partners. The firms in our study report a concern that sharing information with their competitors may, in subtle ways over time introduce homogeneity into their product offerings and reduce the distinctiveness of each firm. This risk is not identified in prior studies, nor found in the inventory of inter-firm risks compiled by Anderson et al., (2014). The publishing houses see the individual character and publishing attributes of their firm as a key source of competitive advantage that they must protect. Thus, we demonstrate that relational risk comprises not only intentional acts to appropriate an inequitable distribution of rents from an alliance, but can extend to unwitting behaviours that reduce available rents to all partners.

We also find that regulatory risk is a particularly salient concern in the co-opetitive context (cf. Anderson et al., 2014). Any exchange of information that results in collaborating firms gaining financial advantage over their customers or suppliers exposes them to the risk of perceived or actual collusion, potentially bringing them foul of anti-competition legislation. Thus, the competitor firms in the alliance we study are careful to ensure mechanisms are in place (such as confidentiality clauses) to alleviate both perceptions of, and the potential for, anti-competitive behaviour. 


\subsection{The role of formal contracts for the control of co-opetitive alliances}

Formal contracts are evident in relation to the vertical activities of the alliance where there are separate outsourcing contracts between Austen and each of the purchasers. We find that these formal contracts play several roles. First, they are considered by firms to mitigate regulatory risk in both the vertical and horizontal activities of the alliance where standard clauses, such as those relating to confidentiality, help to reduce both perceptions and breaches of anti-competitive behaviour. While this contrasts with the finding of Anderson et al. (2014) that compliance and regulatory risks are more likely to be associated with informal controls, we do find that relational contracts in place within the alliance also offer important safeguards to this type of risk. Second, they define the nature of the relationship between Austen and the purchasing firm. As such, they are central to managing performance risks within the alliance by specifying many of the requirements for the co-ordination of exchange between firms in the outsourcing activities (Malhotra \& Lumineau, 2011; Williamson, 2012). However, there is a clear disinclination within the alliance to enforce contractual obligations in the event of poor performance. Consistent with extant literature, we find that the firms struggle to write complete contracts (Anderson \& Dekker, 2014), due largely to the difficulties and costs associated with writing contracts for all foreseeable eventualities. While the vertical activity in the sales alliance is highly measureable (number/length of sales calls, volume of sales, etc.) there is a great deal of uncertainty exerting influence on the final sales success of each book. We find that this reluctance to enforce contractual obligations arises not only from the difficulties of contracting for performance, but also, more importantly, from the broader view of the benefits of collaborations taken by each partner. Finally, despite evidence of poor behaviours or performance, we find little inclination to employ sanctions consistent with the notion that parties are not always able to distinguish misfeasance from a genuine misunderstanding and that penalties may exert a high cost on the punisher (Jones et al., 1997). 
6.3 The role of relational contracting in co-opetitive alliances

Our evidence indicates that relational contracting plays an important role in mitigating the risks associated with both the vertical and horizontal activities of the sales alliance. Based on our empirical findings, we structure our analysis below around mechanisms of relational contracting, factors that sustain relational contracting in this setting, and the outcomes of relational contracting. Our findings are summarised in Table 1. Finally, we conclude this section by discussing our findings in terms of economics-based arguments about the nature of exchanges between firms in co-opetitive alliances.

[Insert Table 1 here]

\subsubsection{Mechanisms of relational contracting}

Our findings indicate that a range of mechanisms address the risks of working with competing partners and support relational contracts between the firms in our study. Commitment to a shared set of values, institutionalised through social ties, is a means to signal to competing partners a willingness to engage in co-operative actions and to restrain from opportunistic behaviours. In addition to the values of the group, we also find evidence of implicit understandings between the firms, such as unwritten codes of conduct (for example, around poaching staff from other firms within the alliance), that indicate the scope and potential consequences of unacceptable behaviours. The implicit threat of collective sanctions, such as exclusion from joint activities, further helps to promote desirable behaviours.

Meetings and other informal contacts between the managing directors provide the means through which they demonstrate their commitment to the collective values of the alliance and help to create a sense of solidarity that further encourages desirable behaviours. Gatherings involving member firms also enable them to share information about alliance activities and relationships, including reputational information about other partners, that can help to deter opportunistic behaviour as well as help to allay misunderstandings (cf. Gibbons \& Henderson, 2012). Importantly, meetings also provide the means to monitor each other's behaviour and provide assurances that partners will adhere to established norms 
and shared values and act in ways that will not run foul of anti-competition legislation. The firms are able to control the amount and scope of information they share through the involvement of only their most senior personnel (usually the managing and sales directors) in alliance activities. Careful management of contacts between firms is also essential in preserving the unique identity of each firm from the risk of homogeneity that may occur during the exchange of information and ideas.

Crucially, the sales alliance consists of only six firms from the many that constitute the independent publishing sector. Prior studies (for example, Jap et al, 2003; Jones et al, 1997; Williamson, 1993) indicate that restricting the number of firms in an alliance is likely to enhance the effectiveness and efficiency of relational contracting. Our evidence indicates support for this argument in several ways. First, by restricting itself to a small number of firms the alliance is exposed to fewer potential occurrences of misappropriation or opportunism than if it were to contain a greater number of partners Second, a smaller number of firms offers greater potential for repeated interactions. Our respondents provided many examples of meetings and informal gatherings involving different combinations of alliance partners. Increased contact between member firms enhances both the accuracy of information about partners and the overall quality of monitoring undertaken. This is particularly salient in the context of our study, where competing partners possess a high level of knowledge of each other's businesses and can therefore readily identify undesirable behaviours. The risks of homogeneity in product offerings and anti-competitive behaviour increase the importance of high-quality and frequent monitoring among these firms. Third, by restricting membership to those firms that demonstrate commitment to a set of shared values the alliance is able to reduce the overall level and scope of monitoring required. For example, our respondents referred to monitoring only in informal terms, indicating that, for example, attendance at meetings was neither formally acknowledged nor recorded.

We find that many of the mechanisms of relational contracting that operate within the sales alliance are not unique to this particular alliance but are also evident in the other alliances in which the various 
partners collaborate together. ${ }^{14}$ For example, the shared values and behavioural norms at play in the sales alliance, similarly influence the printing alliance and the production alliance. While meetings may be specific to the sales alliance they permit monitoring of behaviours across all alliances, as do informal gatherings between the managing directors. This suggests that relational contracts need not be redeveloped or re-negotiated as new alliances are forged between partners, and indicates that, for this particular group of firms, they provide an effective and efficient form of contracting across multiple alliances.

\subsubsection{Factors that sustain relational contracts}

Our findings indicate several factors that enable relational contracts to develop and be sustained. Prior shared experiences facilitate efficient selection of partners based on shared values, and enable accurate monitoring of partners. Repeated exchanges and social ties promote an understanding of each other's activities and desired outcomes, and hence reduce the monitoring required of each partner. Furthermore, the flexibility to join or abstain from any activity assures firms that partners are willing participants, potentially reducing the likelihood of undesirable behaviours. Underpinning the selection of controls to manage the relationships within the alliance is an awareness by the firms that the long-term gains from co-operation depend on conscious efforts to regulate their own behaviour. Self-regulating behaviours ensure a firm's continued participation in joint activities and reduce the monitoring required of its partners. The importance of self-regulating behaviour is apparent, for example, in Austen's assertion that it does not privilege its own book titles over those of its partners despite the short-term financial benefits this would afford. Austen's partners are sceptical of this claim, but have no evidence to the contrary and are cognisant of the longer-term benefits to Austen that accrue from the alliance. The firms are similarly reliant on self-regulating behaviours in other joint activities of the alliance. We find that self-regulating behaviour involves an implicit consideration of the likely benefits to co-operation and potential costs to opportunism for each firm - the 'shadow of the future' - and takes place in a context

\footnotetext{
${ }^{14}$ Similar, dense networks of inter-related firms are reported in other industries (see Baker, Gibbons \& Murphy, 2008).
} 
in which partners are able to monitor each other's behaviour. Self-regulating behaviour reflects the concept of 'enlightened self-interest' (Chaserant, 2003; Williamson, 1993), and supports an economic rationale for all activities in which the firms participate.

Finally, our data support theoretical notions that the various mechanisms and sustaining factors associated with relational contracting interact and reinforce each other (e.g. Jones et al, 1997). For example, regular interactions between the firms in our study provide continual opportunities to share information about each other's behaviours whilst simultaneously reinforcing the shared values and sense of solidarity that, in turn, act to encourage self-regulating behaviours.

\subsubsection{Outcomes of relational contracting}

By mitigating the various relational risks between the firms in the alliance, relational contracting is able to support a number of informal agreements. These agreements cover both direct exchanges in horizontal activities between partners, for example compromises in relation to book launches, as well as joint exchanges between partners of the alliance in relation to suppliers and customers external to the collaborations. The agreements between the firms are contemporaneous and cover various activities within the alliance. Some agreements are made on a regular basis, while others, such as those relating to joint marketing communications, are discrete, can involve any number of partners, and are not dependent on the activities of the other firms.

Consistent with the management and economics literatures (cf. Jap \& Anderson, 2003; Williamson, 1993), our findings indicate that repeated exchanges between the firms across the various activities reduce the risks of short-term opportunism and support the development of realistic, or credible, commitments. For example, agreements about joint marketing communications depend on the ability and self-interest of partners to fulfil their obligations. We find no evidence that firms make promises they are unlikely to keep. Again consistent with extant theory, our data suggest that the firms avoid committing themselves to activities or actions that they do not believe they can undertake (Williamson, 1993). For example, the firms acknowledge that collaborative activities are likely to fail unless the 
potential benefits to all participating firms are very high, thus indicating the calculus of gains and losses that underpins their commitments to each other.

\subsubsection{The myth of trust}

The behaviours of the firms in our study can be explained by reference to the 'shadow of the future' (Gibbons \& Henderson, 2012). The firms in our study rely on particular relational mechanisms as lowcost alternatives to formal contracts because 'they work'. We suggest that the firms expressly avoid formal contracts, not because they 'trust' each other, but because relational contracts offer an effective and efficient way to manage the alliance. In particular, in the co-opetitive setting we explore, the firms possess both the ability and incentive to monitor closely each other's behaviour. Furthermore, their indepth knowledge of each other's business enables them to understand, rather than simply believe or trust, the basis on which commitments are made. As such, the relational contracts between the firms in our study provide cost-effective safeguards against opportunistic behaviours.

While our respondents describe their relationships in terms of 'trust' and 'trustworthy behaviour', they simultaneously refer to 'self-interested behaviour', 'enlightened self-interest', and 'smart capitalism'. These admissions of calculativeness exist alongside examples of self-regulating behaviours and a range of observable safeguards such as monitoring of partners. Our data thus demonstrate that the firms are cognisant of the inherent risks in co-operating with close competitors, the behavioural norms that underpin the relationships, the potential actions that could end a firm's involvement in the alliance, the various safeguards in place to manage exchanges between the firms, and the importance of enlightened self-interest as a motivation for continuing to participate in the activities. Our findings thus support economics-based arguments that the concept of 'trust' can obscure the variety, nature, and extent of safeguards that manage inter-firm relations (Williamson, 1993). In fact, firms that rely on trust to manage their relationships with other firms may face increased costs if they neglect to 'recognise, mitigate, and price out contractual hazards in a discriminating way' (Williamson, 1993: 485). As such, we suggest that the concept of 'trust' adds neither to explanations nor predictions about the management 
of risks within the alliance, indicating that it is more appropriately described as an ex post labelling of personal affect by those involved in economic exchange (Barney \& Hansen, 1994).

\subsection{The relation between formal contracts and relational contracts in a co-opetitive setting}

Finally, we examine the relation between the use of formal contracts and relational contracts to manage alliance risks of co-opetition. The literature is equivocal as to whether formal and relational contracts are substitutes or complements (see, for example, Cao \& Lumineau, 2015; Schepker et al., 2014). In our setting, we find clear evidence that relational contracts can substitute for formal contracts to mitigate risks within co-opetitive alliances. Respondents in our study viewed the use of formal contracts as antithetical to the maintenance of effective working relationships with their alliance partners (the management of relational risks). This finding is consistent with several other studies that have assumed that the main function of formal contracts is control (Cao \& Lumineau, 2015). However, in our study respondents also identify the possible co-ordination role of formal contracts. Despite evidence that formal contracts are used for co-ordination purposes in our setting respondents still report a hesitance to enforce formal contracts, even to mitigate performance risks (i.e. manage performance risks). While formal contracts do reassure firms as to the management of regulatory risk, firms were also confident that breaches of anti-competition regulations would be deterred (or detected) through relational contracting mechanisms (i.e. regulatory risk is also managed via relational contracting). Thus, our findings contradict those of Woolthuis, Hillebrand and Nooteboom (2005) who contend that when formal contracts support co-ordination, as well as control, they may signal a commitment to the relationship that reinforces relational contracting (i.e. formal and relational contracts are complements). In our setting, formal contracting does not seem to add value above that of relational contracting, nor does it seem to facilitate shared values or understandings or other attributes of relational contracting. There are several plausible explanations for this finding. First, the literature suggests that the temporal order in which formal and relational contracts are developed may influence the relationship between the two. In our setting, attributes of relational contracting (for example, social ties and shared values) pre-dated the formal contracts. Thus, the 'security' afforded by formal contracts is not required to 
facilitate relational contracting (cf. Huber et al., 2013) and relational contracts alone are sufficient for control purposes. An alternative plausible explanation is that in this sector firms have a preference for relational contracts. Our participants referred frequently to the 'gentlemanly' nature of the publishing industry as an explanation as to why formal contracts were not used for the control of the sales alliance. Other studies have reported similar preferences for the use of either formal or relational contracts (cf. Bolton et al., 1994; Li et al., 2010). Our findings provide further evidence that temporal sequencing and preferences may impact the nature of the relationship between formal and relational contracts.

\section{Conclusions}

Relational contracting, while used frequently in management and economics-based research to investigate and explain relationships between firms, has received scant attention in the management control literature. We identify the alliance risks that arise in the context of a co-opetitive alliance and examine, through the concepts of relational and formal contracting, the control mechanisms employed to mitigate those risks. While the control of inter-firm relationships is studied extensively, relatively fewer studies examine controls in contexts other than buyer-supplier activities. To date, the literature has not progressed far beyond propositions as to what specific risks we may expect in co-opetitive alliances other than suggesting that the relational risks are likely to be 'more acute'. We confirm misappropriation and opportunism as key alliance risks and also identify what we believe to be a previously unreported relational risk arising in alliances between non-competing partners; namely, the risk of homogeneity in firm 'identities' and product offerings. We also highlight the importance of regulatory risk in this particular setting. Importantly, our context allows us to examine more closely the contention that risks are intensified in alliances between competitors. As suggested in prior literature, we observe that the ability of competitors to readily identify and assimilate information and resources of value within the alliance is enhanced, given they operate in the same business sectors. However, we find that co-operation with competitors also has an 'off-setting' effect not previously discussed in the literature. That is, while the ability to misappropriate or act opportunistically may be more acute, the ability of other partners to the alliance to foresee such actions by their competitors mitigates the level 
of risk in the alliance. Finally, by collecting data from all members to the alliance, we increase the confidence that we have captured all salient relational risks in our co-opetitive setting (Caglio \& Ditillo, 2008)

In examining controls in co-opetitive alliances we attempt to move beyond the contributions of extant studies, which largely provide evidence that where alliance risks are more complex or acute, partners to an alliance will respond by writing more complex formal contracts and will use these more intensely for control purposes. Our findings suggest that relational contracts can substitute for formal contracts in co-opetitive contexts and are, in fact, the preferred means of mitigating alliance risks in our study. In investigating the role of relational contracts, we introduce to the management accounting and control literature a comprehensive organising framework, informed by our empirical data, within which relational contracts can be studied in greater depth in future studies. This framework identifies mechanisms of relational contracts, including shared values, group norms and implicit understandings, as well as factors that sustain such contracts, including self-regulating behaviours and enlightened selfinterest. Importantly, our data also suggest that the mechanisms of relational contracting can span multiple alliances. Finally, we draw on the concepts of relational contracting to offer a more substantive explanation of co-operative behaviour between co-opetitive partners than is provided by the notion of 'trust'. In particular, we demonstrate how self-regulating behaviours, based on calculated risk-taking by partners and notions of 'enlightened self-interest', demonstrate a willingness to sacrifice short-term gains in order to protect longer-term interests.

This study is subject to several limitations. Case-based research gives rise to the potential for researcherinduced bias during both data collection and analysis. Careful attention to the design and execution of this study go some way to mitigating these issues, as does the use of dual researchers in the data coding and analysis phase (Miles \& Huberman, 1994). Also, while the use of a case-study method and qualitative data facilitate the investigation of complex relations, it necessarily restricts the statistical generalisability of the research findings (Brownell, 1995; Yin, 2003). While we do not claim that interfirm alliances in this sector are representative of co-opetitive activity in other industries, they are a 
useful starting point from which to investigate the under-researched phenomenon of relational contracting. Further, we acknowledge that our data come from a small sample that was purposeselected. Finally, while we investigate the use of formal and relational contracting to mitigate performance risk, our study does not seek to evaluate formally the success or otherwise of the particular collaborations in our study.

The findings from our study suggest several fruitful avenues for further research. Future studies could explore the nature of relational contracting in different types of inter-firm relations, to provide further evidence of the relationship between specific alliance risks and the role of relational contracts. There is also much scope to examine more closely the mechanisms of relational contracting and the means through which relational contracts are sustained. While social controls are researched extensively within the management control literature, there remains scope to enhance understanding of the interrelation between specific elements of social controls, such as shared values and group norms. Of the broader relational contracting mechanisms, which mechanisms are most important, and why? What factors determine a firm's choice amongst viable contracting mechanisms? How do relational contracts change over time, and what are the determinants of any such change? Similarly, the relation between formal and relational contracts remains relatively under-explored. What other factors may influence the choice between these governance mechanisms and the nature of the relation between them? Other economics-based theories, such as identity economics, might offer a useful means of exploring further the role of individuals in the selection and use of inter-firm control. There also remains much to understand in relation to how formal and relational contracts affect the performance outcomes of alliances. Furthermore, this is the first study of which we are aware in the management control literature that investigates the control of an alliance of firms engaged in co-opetitive activity. Large scale archival and survey data that can provide more generalisable insights into the risks and control mechanisms in this form of alliance would be of interest. Further, firms are likely to vary in their ability to extract benefits from the alliance and so an understanding of firm-level controls that may assist firms to extract value from an alliance could provide interesting insights. Finally, recent relational contracting papers in the management literature (e.g. Gibbons \& Henderson, 2012; Schepker et al, 2014) adopt an 
economics perspective when examining 'trust'. This may be an indication that economics-based arguments are beginning to prevail in management research. Researchers in the area of management control may similarly wish to consider the usefulness of trust as an analytical device for understanding inter-firm governance.

In summary, this study examines the role of formal and relational contracts for the control of coopetitive alliances, providing a timely contribution to ongoing debates relating to the nature and use of relational contracts, and more broadly the management of various forms of inter-firm relationships. 


\section{Appendix 1 - Research Setting}

\begin{tabular}{|c|c|c|}
\hline $\begin{array}{l}\text { Publishing } \\
\text { House }\end{array}$ & Description of Publishing House & Interviewees and Duration of Interview \\
\hline Austen & $\begin{array}{l}\text { The largest and oldest of the five houses, Austen has a substantial and high-quality backlist comprising } \\
\text { both fiction and non-fiction books. Austen has sought to reduce its dependence on the vagaries of book } \\
\text { publishing by contracting out the use of its sales function to other independent houses. }\end{array}$ & $\begin{array}{l}\text { Managing Director / Publishing Editor }-1 \text { hour } \\
\text { (first visit), } 1 \text { hour (second visit) } \\
\text { Sales Director }-1 \text { hour }\end{array}$ \\
\hline Brontë & $\begin{array}{l}\text { Brontë has a very small but rapidly expanding backlist of literary fiction and non-fiction. The firm also } \\
\text { has a third-party agreement to publish books commissioned by another small publisher included in this } \\
\text { study. This earns Brontë commission on each book sold and provides some revenue stability and } \\
\text { insulation in a changeable industry. }\end{array}$ & $\begin{array}{l}\text { Managing Director / Publishing Editor }-1 \text { hour } \\
\text { (first visit), 11/4 hours (second visit), } 1 \text { hour (third } \\
\text { visit) } \\
\text { Sales Director }-1 \text { hour } \\
\text { Publicity Director / Associate Publisher }-1 \text { hour } \\
\text { Production Manager }-3 / 4 \text { hour } \\
\text { Rights Director }-3 / 4 \text { hour } \\
\text { Finance Director }-1 \text { hour }\end{array}$ \\
\hline Carroll & $\begin{array}{l}\text { Carroll publishes a variety of fiction and non-fiction book titles. An important strand of Carroll's } \\
\text { publishing strategy is an extensive third-party arrangement to produce non-fiction books for a firm } \\
\text { external to this alliance. }\end{array}$ & $\begin{array}{l}\text { Managing Director / Publishing Editor }-1 \text { hour } \\
\text { (first visit), } 1 \text { hour (second visit) } \\
\text { Sales Director }-1 \text { hour }\end{array}$ \\
\hline Dickens & $\begin{array}{l}\text { Dickens is renowned in the industry for its ability to innovatively rebrand and repackage celebrated } \\
\text { works as well as commission authors to write works of non-fiction. }\end{array}$ & Managing director -1 hour \\
\hline Eliot & $\begin{array}{l}\text { Eliot is the youngest of the firms in our study, but has expanded rapidly since achieving early successes } \\
\text { with fiction, non-fiction and children's titles. }\end{array}$ & Managing Director / Publishing Editor - 1 hour \\
\hline Gaskell & $\begin{array}{l}\text { Gaskell represents the successful amalgamation of several smaller publishing houses, specialising in } \\
\text { literary fiction and upmarket non-fiction, }\end{array}$ & Managing Director / Publishing Editor - 1 hour \\
\hline Hardy & $\begin{array}{l}\text { Collaborative partner of Brontë; a small publishing offshoot of a larger media group that outsources } \\
\text { the production processes (printing, warehousing, distribution) of its trade publishing to Brontë. }\end{array}$ & $\begin{array}{l}\text { Relationship Manager, Publishing - } 1 \text { hour (first } \\
\text { visit), } 20 \text { mins (second visit) }\end{array}$ \\
\hline
\end{tabular}




\begin{tabular}{|c|c|c|}
\hline $\begin{array}{l}\text { Other Alliance } \\
\text { Partners }\end{array}$ & Type of Firm & Interviewees and Duration of Interview \\
\hline Suppliers & $\begin{array}{l}\text { Graphic design company } \\
\text { Printing company } \\
\text { Warehousing \& distribution company } \\
\text { Specialist sales organisation }\end{array}$ & $\begin{array}{l}\text { Art Director }-3 / 4 \text { hour } \\
\text { Managing Director }-1 \text { hour } \\
\text { Managing Director }-3 / 4 \text { hour } \\
\text { Managing Director }-1 \text { hour }\end{array}$ \\
\hline Other & Trade Association Body & Executive Board Member $-1 \frac{1}{1} 2$ hours \\
\hline
\end{tabular}




\section{Appendix 2 - Evidence of relational contracting in related alliances}

\begin{tabular}{|l|}
\hline Co-opetitive Alliance \\
\hline Printing alliance (horizontal \\
activity between Austen, \\
Carroll, Dickens) - involves the \\
consolidation of the total \\
number of printing suppliers to \\
members of the alliance and the \\
pooling of printing volumes to \\
obtain economies of scale. Each \\
member of the alliance enters \\
into separate contracts with the \\
selected suppliers. The \\
objective of group purchasing of \\
printing services is to enhance \\
purchasing power and access \\
economies of scale.
\end{tabular}

\section{Alliance Risks}

Misappropriation of proprietary information by partners, e.g. the format and presentation of each book

"In an ideal world, you would never ever reveal to a competitor any information about your pipeline, or your preferred terms of trade or whatever...but we have no choice... if you want, need, to reduce your printing costs, then you have to put your cards on the table along with everyone else." (Managing Director, Austen)

Opportunistic behaviour, e.g. if a member to the alliance should move to another printer it would expose their partners to potentia breach of contract

"[I]fyou agree a certain level of volumes [with printers] and you can't meet them...the risk is that you'll have to carry the additional costs...or [lose] the discounts that you agreed with the printer on the basis of higher volumes." (Managing Director, Austen)

Homogeneity of product offering, e.g. from firms sharing production pipeline information and also from adopting similar book formats as a smaller number of suppliers limits printing choice.

Perceived or actual anti-competitive behaviour in group dealings with printers
Formal and Relational Contracting

Formals contracts to manage the vertical relationship between each firm and the printer (each firm in the alliance enters into a separate contract with each printer)

The firms have an informal agreement to pool printing volumes. Shared values, derived from prior relationships, help to select partner with a similar commitment to the alliance and its objectives. Risks associated with misappropriation and opportunism are further mitigated through, e.g. self-regulating behaviour and monitoring.

"The feedback loops are strong because it would be known very, very quickly if somebody had used a printer outside of the agreement ...first of all I would be surprised if anyone did it in secret and second, if they did it would get to be known very quickly." (Managing Director, Brontë)

Self-regulating behaviours are reinforced by the 'shadow of the future' in that firms have the potential to achieve significant reductions in printing costs if they remain in the alliance and risk exclusion if they go against group norms.

The flexible nature of the arrangement between firms ensures that partners can each agree a contract with the printer that meets their specific requirements

"You might say 'well, we had to use [another printer] because we couldn't get our reprinting in time.", (Managing Director, Brontë) 


\begin{tabular}{|c|c|c|}
\hline $\begin{array}{l}\text { Third party production (vertical } \\
\text { activity between Hardy and } \\
\text { Brontë) - involves Hardy } \\
\text { outsourcing its production } \\
\text { processes to Brontë. The } \\
\text { collaboration provides Hardy } \\
\text { with access to resources. }\end{array}$ & $\begin{array}{l}\text { Misappropriation of proprietary information by Brontë, e.g. Hardy } \\
\text { provides advance information as to the format and presentation of } \\
\text { each book in their pipeline. } \\
\text { "You're trying to protect, your ideas, your content, your } \\
\text { intellectual property...[I]t's a risk that you're exposed to." } \\
\text { (Relationship Manager, Hardy) } \\
\text { Opportunistic behaviour, e.g. the delay of the production process } \\
\text { by Brontë. } \\
\text { "Delaying publication...[is] obviously something that a partner } \\
\text { could do in publishing." (Relationship Manager, Hardy) } \\
\text { Homogeneity e.g. from Brontë unwittingly adopting aspects of } \\
\text { Hardy's product offering or exerting influence on Hardy's } \\
\text { production choices }\end{array}$ & $\begin{array}{l}\text { A formal Heads of Agreement establishes a general agreement } \\
\text { between the firms to work together. The type and amount of activity } \\
\text { that Bronte will undertake on Hardy's behalf is agreed informally } \\
\text { (relational contract). } \\
\text { "It was defined in a Heads of Agreement between the two } \\
\text { companies. There was never really any sort of guarantee that either } \\
\text { of us would have first option, but the spirit of the agreement was that } \\
\text { we would give Brontë all the work that we could on all the projects } \\
\text { that we work on." (Relationship Manager, Hardy) } \\
\text { The Heads of Agreement gives both firms flexibility in relation to the } \\
\text { extent of its involvement in the collaboration, thus reducing the risk of } \\
\text { undesirable behaviours from a partner that is forced to remain in an } \\
\text { unprofitable or unsuitable alliance. } \\
\text { Risks are mitigated largely through self-regulating behaviours by } \\
\text { Brontë in the knowledge that any misappropriation or opportunism } \\
\text { will be conveyed to other competitors, potentially inhibiting its ability } \\
\text { to engage in future collaborative activities. Brontë acknowledges the } \\
\text { influence of the 'shadow of the future' in its behaviours. } \\
\text { "Immediately we sent a signal to the rest of the trade that we were } \\
\text { around for a while, and that if [Hardy] could trust us then so should } \\
\text { you." (Managing Director, Brontë) } \\
\text { Shared values, e.g. around the importance of maintaining the } \\
\text { uniqueness of each firm, are identical to those expressed in the sales } \\
\text { alliance. They serve to promote desirable behaviours as well as remind } \\
\text { the partners of the risk of homogeneity associated with this alliance. } \\
\text { "The underlying ethos is that it's about the quality of what we do, } \\
\text { it's really the most important thing... Keeping the integrity in the } \\
\text { brand is very important." (Relationship Manager, Hardy) }\end{array}$ \\
\hline
\end{tabular}




\section{References}

Anderson, S. W., Christ, M. H., Dekker, H. C., \& Sedatole, K. L. (2014). Risk in strategic alliances: Field and survey evidence. Journal of Management Accounting Research, 26(1), 1-32.

Anderson, S. W., Christ, M. H., Dekker, H. C., \& Sedatole, K. L. (2015). Do extant management control frameworks fit the alliance setting? A descriptive analysis. Industrial Marketing Management, 46, 36-53.

Anderson, S. W., \& Dekker, H. C. (2005). Management control for market transactions: The relation between transaction characteristics, incomplete contract design, and subsequent performance. Management Science, 51(12), 1734-1752.

Anderson, S. W., \& Dekker, H. C. (2014). The role of management controls in transforming firm boundaries and sustaining hybrid organizational forms. Foundations and Trends in Accounting, 8(2), 75-141.

Baker, G. P., Gibbons, R., \& Murphy, K. J. (2002). Relational contracts and the theory of the firm. The Quarterly Journal of Economics, 117(1), 39-84.

Baker, G. P., Gibbons, R., \& Murphy, K. J. (2008). Strategic alliances: Bridges between "islands of conscious power". Journal of the Japanese and International Economies, 22(2), 146-163.

Bengtsson, M., \& Kock, S. (2000). "Coopetition" in business networks - to cooperate and compete simultaneously. Industrial Marketing Management, 29(5), 411-426.

Bengtsson, M., Eriksson, J., \& Wincent, J. (2010). Coopetition: New ideas for a new paradigm. In Yami, S., Castaldo, S., Battista Dagnino, G. \& Le Roy, F. (Eds.), Co-opetition: Winning Strategies for the $21^{\text {st }}$ Century (pp. 1-16). Cheltenham, UK: Edward Elgar.

Bolton, M. K., Malmrose, R., \& Ouchi, W. G. (1994). The organization of innovation in the United States and Japan: Neoclassical and relational contracting. Journal of Management Studies, 31(5), 653-679.

Brandenburger, A., \& Nalebuff, B. (1996). Co-opetition. New York: Doubleday.

Brownell, P. (1995). Research Methods in Management Accounting. Melbourne, Victoria: Cooper \& Lybrand and Accounting Association of Australia and New Zealand.

Burkert, M., Ivens, B. S., \& Shan, J. (2012). Governance mechanisms in domestic and international buyer-supplier relationships: An empirical study. Industrial Marketing Management, 41(3), 544556.

Caglio, A. \& Ditillo, A. (2008). A review and discussion of management control in inter-firm relationships: Achievements and future directions. Accounting, Organizations \& Society, 33(7/8), 865-898.

Caglio, A. \& Ditillo, A. (2012). Opening the black box of management accounting information exchanges in buyer-supplier relationships. Management Accounting Research, 23, 61-78.

Cannon, J. P., Achrol, R. S., \& Gundlach, G. T. (2000). Contracts, norms, and plural form governance. Journal of the Academy of Marketing Science, 28(2), 180-194.

Cao, Z., \& Lumineau, F. (2015). Revisiting the interplay between contractual and relational governance: A qualitative and meta-analytic investigation. Journal of Operations Management, 33-34, 15-42.

Carson, S. J., Madhok, A., \& Wu, T. (2006). Uncertainty, opportunism, and governance: The effects of volatility and ambiguity on formal and relational contracting. Academy of Management Journal, 49(5), 1058-1077.

Chaserant, C. (2003). Cooperation, contracts and social networks: From a bounded to a procedural rationality approach. Journal of Management and Governance, 7(2), 163-186.

Coad, A. F., \& Cullen, J. (2006). Inter-organisational cost management: Towards an evolutionary perspective. Management Accounting Research, 17(4), 342-369.

Cohen, J., \& Levinthal, D. A. (1990). Absorptive capacity: A new perspective on learning and innovation. Administrative Science Quarterly, 35, 128-152. 
Czakon, W., Mucha-Kuś, K. (2014). Coopetition research landscape - a systematic literature review 1997-2010. Journal of Economics and Management, 17, 121-150.

Das, T. K., \& Teng, B.-S. (1996). Risk Types and Inter-Firm alliance Structures. Journal of Management Studies, 33(6), 827 - 843.

Das, T. K., \& Teng, B.-S. (2001). Trust, control, and risk in strategic alliances: An integrated framework. Organization Studies, 22(2), 251-283.

Das, T. K., \& Teng, B.-S. (2003). Partner analysis and alliance performance. Scandinavian Journal of Management, 19(3), 279-308.

Dekker, H. C. (2004). Control of inter-organizational relationships: Evidence on appropriation concerns and coordination requirements. Accounting, Organizations and Society, 29(1), 27-49.

Dekker, H. C. (2016). On the boundaries between intrafirm and interfirm management accounting research. Management Accounting Research, 31, 86-99.

Ding, R., Dekker, H. C., \& Groot, T. (2013). Risk, partner selection and contractual control in interfirm relationships. Management Accounting Research, 24, 140-155.

Emsley, D., \& Kidon, F. (2007). The relationship between trust and control in international joint ventures: Evidence from the airline industry. Contemporary Accounting Research, 24(3), 829-858.

Fernandez, A-S., Le Roy, F., \& Gnyawali, D. R. (2014). Sources and management of tension in coopetition case evidence from telecommunications satellites manufacturing in Europe. Industrial Marketing Management, 43, 222-235.

Germano, W. P. (2008). Getting it Published: A Guide for Scholars and Anyone Else Serious about Serious Books.( $2^{\text {nd }}$ ed.). Chicago: The University of Chicago Press.

Gibbons, R., \& Henderson, R. (2012). Relational contracts and organizational capabilities. Organization Science, 23(5), 1350-1364.

Gil, N. (2009). Developing cooperative project client-supplier relationships: How much to expect from relational contracts? California Management Review, 51(2), 144-169.

Gnyawali, D. R., \& Madhavan, R. (2001). Cooperative networks and competitive dynamics: A structural embeddedness perspective. The Academy of Management Review, 26(3), 431-445.

Gnyawali, D. R., \& Park, B. J. (2009). Co-opetition and technological innovation in small and mediumsized enterprises: A multilevel conceptual model. Journal of Small Business Management, 47(3), 308-330.

Grafton, J., Abernethy, M. A., \& Lillis, A. M. (2011). Organisational design choices in response to public sector reforms: A case study of mandated hospital networks. Management Accounting Research, 22(4), 242-268.

Granovetter, M. (1985). Economic and social structure: The problem of embeddedness. American Journal of Sociology, 91, 481-510.

Gulati, R., Nohria, N., \& Zaheer, A. (2000). Strategic networks. Strategic Management Journal, 21(3), 203-215.

Gulati, R., \& Singh, H. (1998). The architecture of cooperation: Managing coordination costs and appropriation concerns in strategic alliances. Administrative Science Quarterly, 43(4), 781-814.

Gnyawali, D. R., Madhavan, R. M., He, J., \& Bengtsson, M. (2012). Contradictions, dualities and tensions in cooperation and competition: A capability based framework. Working Paper-Annual Meeting of the Academy of Management, Boston MA.

Hamel, G. (1991). Competition for competence and inter-partner learning within international strategic alliances. Strategic Management Journal, Winter Special Issue, 12, 83-103.

Heide, J. B., John, G. (1992). Do norms matter in marketing relationships? Journal of Marketing, 56(2), $32-44$.

Huber, T. L., Fischer, T. A., Dibbern, J., \& Hirschheim, R. (2013). A process model of complementarity and substitution of contractual and relational governance in IS outsourcing. Journal of Management Information Systems, 30(3), 81-114. 
Jap, S. D., \& Anderson, E. (2003)._Safeguarding Interorganizational Performance and Continuity Under Ex Post Opportunism, Management Science, 49(12), 1684-1701.

Johansson, T., \& Siverbo, S. (2011). Governing cooperation hazards of outsourced municipal low contractibility transactions: An exploratory configuration approach. Management Accounting Research, 22, 292-312.

Khanna, T., Gulati, R., \& Nohria, N. (1998). The dynamics of learning alliances. Strategic Management Journal, 19(3), 193-201.

Langfield-Smith, K. (2008). The relations between transactional characteristics, trust and risk in the start-up phase of a collaborative alliance. Management Accounting Research, 19(4), 344-364.

Li, Y., Xie, E., Teo, H-H., \& Peng, M. W. (2010). Formal control and social control in domestic and international buyer-supplier relationships. Journal of Operations Management, 28, 333-344.

Macneil, I. R. (1974). The many futures of contracts. Southern California Law Review, 47, 691-816.

Mahama, H. (2006). Management control systems, cooperation and performance in strategic supply relationships: A survey in the mines. Management Accounting Research, 17, 315-339.

Malhotra, D., \& Lumineau, F. (2011). Trust and collaboration in the aftermath of conflict: The effects of contract structure. Academy of Management Journal, 54(5), 981-998.

McCracken, G. D. (1988). The Long Interview (Vol. 13). California: Sage Publications.

Miles, M. B., \& Huberman, A. M. (1994). Qualitative Data Analysis: An Expanded Sourcebook (2nd ed.). California: Sage Publications.

Minichiello, V., Aroni, R., Timewell, E., \& Alexander, L. (1995). Indepth Interviewing: Principles, Techniques, Analysis (2nd ed.). Melbourne: Addison Wesley Longman.

Möllering, G. (2014). Trust, calculativeness, and relationships: A special issue 20 years after Williamson's warning. Journal of Trust Research, 4(1), 1-21.

Morris, M., Kocak, A., \& Özer, A. (2007). Coopetition as a small business strategy: Implications for performance. Journal of Small Business Strategy, 18(1), 35-55.

Mouritsen, J., \& Thrane, S. (2006). Accounting, network complementarities and the development of inter-organisational relations. Accounting, Organizations \& Society, 31(3), 241-275.

Neumann, K. (2010). Ex ante governance decisions in inter-organizational relationships: A case study in the airline industry. Management Accounting Research, 21, 220-237.

Park, S. H., \& Russo, M. V. (1996). When competition eclipses cooperation: An event history analysis of joint venture failure. Management Science, 42(6), 875-890.

Poppo, L., \& Zenger, T. (2002). Do formal contracts and relational governance function as substitutes or complements? Strategic Management Journal, 23, 707-725.

Poppo, L., Zhou, K. Z., Zenger, T. R. (2008). Examining the conditional limits of relational governance: Specialized assets, performance ambiguity, and longstanding ties. Journal of Management Studies, 45(7), 1195-1216.

Sambasivan, M., Siew-Phaik, L., Mohamedd, Z. A., Leong, Y. C. (2013). Factors influencing strategic alliance outcomes in a manufacturing supply chain: Role of alliance motives, interdependence, asset specificity and relational capital, Int. J. Production Economics 141, 339-351.

Schepker, D. J., Oh, W-Y., Martynov, A., \& Poppo, L. (2014). The many futures of contracts: Moving beyond structure and safeguarding to coordination and adaptation. Journal of Management, 40(1), 193-225.

Schreiner, M., Kale, P., \& Corsten, D. (2009). What really is alliance management capability and how does it impact alliance outcomes and success? Strategic Management Journal, 30, 1395-1419.

Smith, K. G., Carroll, S. J., \& Ashford, S. J. (1995). Intra- and interorganizational cooperation: Toward a research agenda. Academy of Management Journal, 38(1), 7-23.

Thomason, S. J., Simendinger, E., \& Kiernan, D. (2013). Several determinants of successful coopetition in small business. Journal of Small Business and Entrepreneurship, 26(1), 15-28. 
Thrane, S., \& Hald, K. S. (2006). The emergence of boundaries and accounting in supply fields: The dynamics of integration and fragmentation. Management Accounting, 17(3), 288-314.

Tivnan, T., \& Lewis, J. (2015a). Review of the year 2014: Publishers - overview. Bookseller, January 15.

Tidström, A. (2014). Managing tensions in coopetition. Industrial Marketing Management, 43, 261 271.

Tivnan, T., \& Lewis, J. (2015b). Review of the year 2014: Publishers - The big three and beyond. Bookseller, January 15.

Tomkins, C. (2001). Interdependencies, trust and information in relationships, alliances and networks. Accounting, Organizations and Society, 26(2), 161-191.

Uzzi, B. (1996). The sources and consequences of embeddedness for the economic performance of organizations: The network affect. American Sociological Review, 61(4), 674-698.

Uzzi, B. (1997). Social structure and competition in interfirm networks: The paradox ofembeddedness. Administrative Science Quarterly, 41(1), 35-67.

van der Meer-Kooistra, J., \& Scapens, R. W. (2008). The governance of lateral relations between and within organisations. Management Accounting Research, 19(4), 365-384.

van der Meer-Kooistra, J., \& Vosselman, E. G. J. (2000). Management control of interfirm transactional relationships: The case of industrial renovation and maintenance. Accounting, Organizations and Society, 25(1), 51-77.

Williamson, O. E. (1979). Transaction-cost economics: The governance of contractual relations. Journal of Law and Economics, 22(2), 233-261.

Williamson, O. E. (1985). The Economic Institutions of Capitalism. New York: Free Press.

Williamson, O. E. (1993). Calculativeness, trust and economic organizations. Journal of Law and Economics, 36(S1), 453-486.

Williamson, O. E. (2008). Outsourcing: transaction cost economics and supply chain management*. Journal of supply chain management, 44(2), 5-16.

Williamson, O. E. (2012). Transaction cost economics: What are the questions? Working Paper - The University of California, Berkeley.

Windolph, M., \& Moeller, K. (2012). Open-book accounting: Reason for failure of inter-firm cooperation? Management Accounting Research, 23(1), 47-60.

Woolthuis, R. K., Hillebrand, B., \& Nooteboom, B. (2005). Trust, contract and relationship development. Organization Studies, 26(6), 813-840.

Yami, S., Castaldo, S., Battista Dagnino, G., \& Le Roy, F. (2010). Co-opetition strategies: Towards a new form of inter-organizational dynamics? In Yami, S., Castaldo, S., Battista Dagnino, G. \& Le Roy, F. (Eds.), Co-opetition: Winning Strategies for the $21^{\text {st }}$ Century (pp. 1-16). Cheltenham, UK: Edward Elgar.

Yin, R. K. (2003). Case Study Research: Design and Methods (3rd ed. Vol. 5). Beverly Hills CA: Sage.

Zhou, K. Z., \& Xu, D. (2012). How foreign firms curtail local supplier opportunism in China: Detailed contracts, centralized control, and relational governance. Journal of International Business Studies, 43(7), 677-692. 
Figure 1 - Co-opetitive Alliances Studied

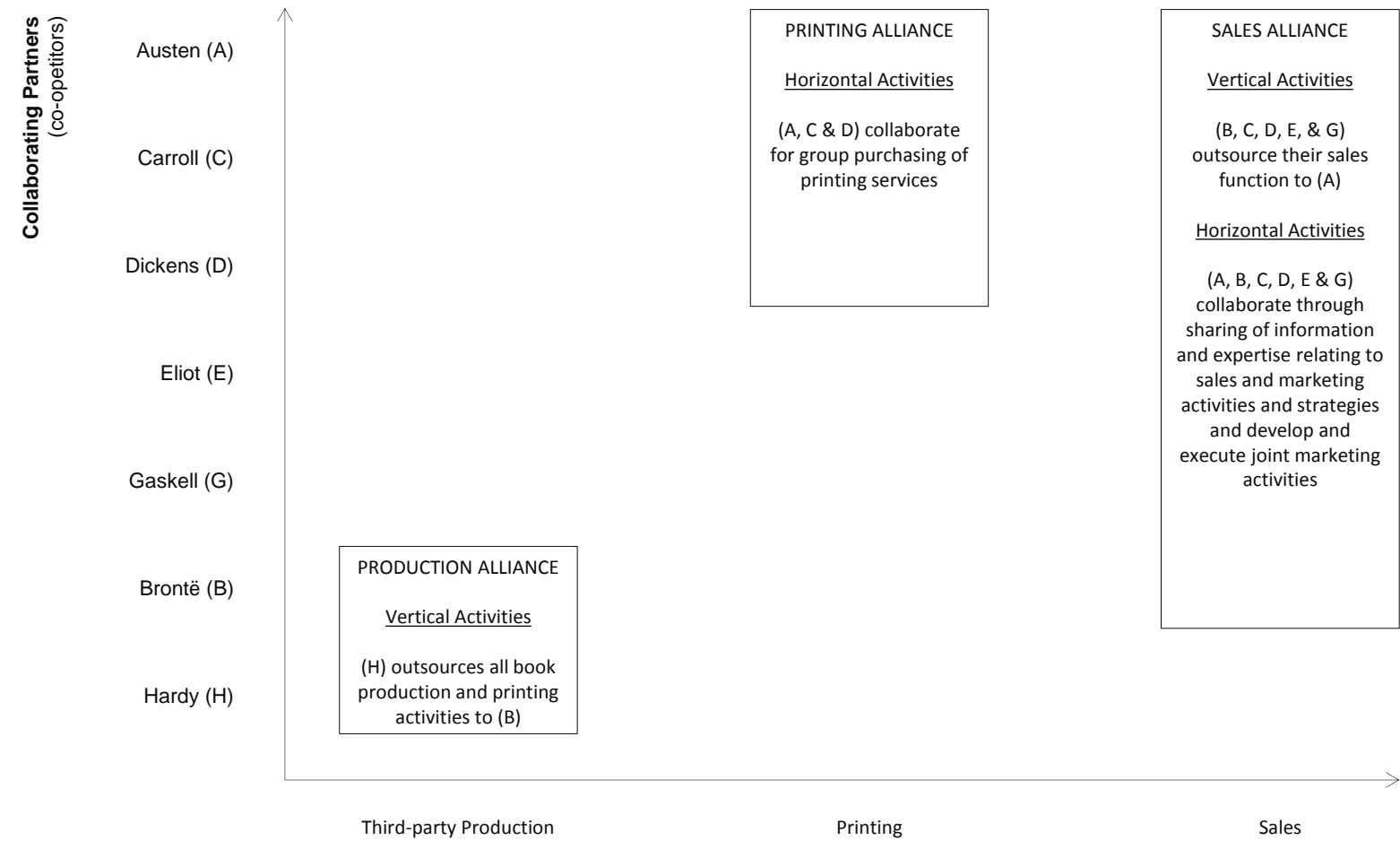

Value Chain 
Table 1 - A Framework for Investigating Relational Contracting

\begin{tabular}{|c|c|c|c|}
\hline Mechanisms & Work by & Sustained by & Outcomes \\
\hline $\begin{array}{l}\text { Shared values } \\
\text { Alliance meetings and } \\
\text { other informal and social } \\
\text { gatherings } \\
\text { Group norms (codes of } \\
\text { conduct, implicit } \\
\text { understandings) } \\
\text { Restricted access to the } \\
\text { alliance } \\
\text { Involvement restricted to } \\
\text { senior personnel } \\
\text { Threat of collective } \\
\text { sanctions }\end{array}$ & $\begin{array}{l}\text { Enabling firms to } \\
\text { demonstrate commitment } \\
\text { to the alliance and to } \\
\text { partners } \\
\text { Building a sense of } \\
\text { solidarity and shared } \\
\text { vision } \\
\text { Facilitating the exchange } \\
\text { of information about } \\
\text { activities and about the } \\
\text { relationships between } \\
\text { partners } \\
\text { Providing firms with the } \\
\text { means to monitor their } \\
\text { partners } \\
\text { Indicating to firms and } \\
\text { potential partners the } \\
\text { implicit rules and } \\
\text { sanctions that underpin } \\
\text { the relationship } \\
\text { Diffusing information } \\
\text { about partners' } \\
\text { reputations } \\
\text { Facilitating partner } \\
\text { selection }\end{array}$ & $\begin{array}{l}\text { Prior and repeated } \\
\text { exchanges between } \\
\text { partners } \\
\text { Social ties between } \\
\text { partners } \\
\text { Self-regulating behaviour } \\
\text { (including restraint from } \\
\text { use of power) } \\
\text { Enlightened self- } \\
\text { interest/shadow of the } \\
\text { future } \\
\text { Flexibility }\end{array}$ & $\begin{array}{l}\text { Informal agreements / } \\
\text { credible commitments } \\
\text { made by each partner }\end{array}$ \\
\hline
\end{tabular}

